\title{
Significance of the Ukrainian loess-palaeosol sequences for Pleistocene climate reconstructions: rock magnetic, palaeosol and pollen proxies ${ }^{1}$
}

\author{
D. V. Hlavatskyi ${ }^{1}$, N. P. Gerasimenko ${ }^{2}$, V. G. Bakhmutov ${ }^{1}$, O. S. Bonchkovskyi ${ }^{2}$, \\ I. B. Poliachenko' ${ }^{1}$ V. V. Shpyra ${ }^{1}$, S. V. Mychak ${ }^{1}$, I. V. Kravchuk ${ }^{2}$, \\ S. I. Cherkes ${ }^{1}, 2021$ \\ ${ }^{1}$ S. I. Subbotin Institute of Geophysics of the National Academy \\ of Sciences of Ukraine, Kyiv, Ukraine \\ ${ }^{2}$ Taras Shevchenko National University of Kyiv, Faculty of Geography, Kyiv, Ukraine \\ Received 2 March 2021
}

\begin{abstract}
Variations of rock magnetic parameters in loess-palaeosol sequences, related to climatic and environmental conditions during their formation, are a powerful tool for palaeoclimate reconstruction. Combined enviromagnetic study of loess deposits in Ukraine and its assessment for the palaeoreconstruction purposes are carried out in the framework of the National Research Foundation of Ukraine project 2020.02/0406 'Magnetic proxies of palaeoclimatic changes in the loess-palaeosol sequences of Ukraine'. Environmental/ climatic reconstructions of the past are fulfilled using a significant number of palaeoindicators: morphology and lithological properties of palaeosols and loesses, their pollen assemblages and a wide range of magnetic characteristics. In this paper, we present a multi-proxy approach to palaeoenvironmental reconstructions, and introduce preliminary results obtained from magnetic susceptibility of loess-palaeosol sequences in the northern (at Vyazivok), central (Stari Kaydaky) and southern (Roksolany) parts of the Ukrainian loess belt. The amplitudes of palaeoclimate change established using magnetic proxies are well correlated with the lithological, palaeopedological and palynological patterns of the sites, and with the global oxygen-isotope scale (MIS). Ongoing studies of the Stari Kaydaky section confirm the correlation of the Upper Zavadivka (S3) soil unit and Lower Zavadivka (S4) soil unit with MIS 9 and MIS 11, respectively (this was proved earlier at the Vyazivok and Roksolany sites). The underlying Lubny (S5) pedocomplex likely corresponds to MIS 13, and the Martonosha (S6) pedocomplex to MIS 15. Palaeomagnetic investigations at Stari Kaydaky have not so far reached the Lower Shyrokyne unit, in which the Matuyama - Brunhes boundary has been detected at Roksolany and Vyazivok. The Upper Shyrokyne (S7S1) palaeosol unit has normal polarity and is preliminarily correlated with MIS 17.
\end{abstract}

Key words: loess-palaeosol sequence, rock magnetism, magnetic susceptibility, palaeopedology, palynology, palaeoclimate, stratigraphic correlation.

Introduction. A key to the solution of the urgent problem of the world community global climate change - is a knowledge about the global and regional patterns of climate fluctuations in the past. The history of the past enables the understanding of the present, and it provides a possibility for predictions of the future. Alongside with the wellknown natural 'archives' of palaeoenvironmental events, recorded in ice cores, marine and lake sediments, the Quaternary climatic cycles are also presented in loess-palaeosol

\footnotetext{
${ }^{1}$ Citation: Hlavatskyi, D. V., Gerasimenko, N. P., Bakhmutov, V. G., Bonchkovskyi, O. S., Poliachenko, I. B., Shpyra, V. V., Mychak, S. V., Kravchuk, I. V., \& Cherkes, S. I. (2021). Significance of the Ukrainian loess-palaeosol sequences for Pleistocene climate reconstructions: rock magnetic, palaeosol and pollen proxies. Geofizicheskiy Zhurnal, 43(3), 3-26. https://doi.org/10.24028/gzh.v43i3.236378.
} 
sequences which are another valuable archive of palaeoenvironmental information.

Despite of significant amount of data obtained by Quaternary geology and palaeogeography, the forecasts of future climate change differ significantly. Therefore, nowadays a great attention is paid to implementation of new research methods within a multidisciplinary approach, to the search of new complete sections within the terrestrial archives, and to analysis of the factors that have caused palaeoenvironmetal changes [Vandenberghe, Nugteren, 2001; Buggle et al., 2013; Sümegi et al., 2015, 2019; Marković et al., 2018; Zeeden et al., 2018; Chmielowska, Woronko, 2019; Molnár et al., 2021; Scheidt et al., 2021; Wacha et al., 2021].

The new advances in rock magnetic methodologies and analytical techniques expand our ability to obtain important information on palaeoenvironmental change, including reconstruction of past geomagnetic field variations and environmental parameters, and understanding the processes of loesspalaeosol magnetic properties formation. Palaeoclimatic studies of the key loess-palaeosol sequences in the Chinese Loess Plateau (CLP), Central Asia, Danube Basin and East European Plain [Heller, Liu, 1984; Kukla et al., 1988; Forster et al., 1994; Jordanova, Petersen, 1999; Evans, Heller, 2001, 2003; Rousseau et al., 2001; Buggle et al., 2009; Fitzsimmons et al., 2012; Marković et al., 2015; Necula et al., 2015; Bakhmutov et al., 2017; Chen et al., 2018; Song et al., 2018; Sümegi et al., 2018; Költringer et al., 2020; Bradák et al., 2021; Laag et al., 2021 and many others] have shown that rock magnetic palaeoenvironmental proxies, primarily magnetic susceptibility (MS), display strong similarities and can be correlated with the marine oxygen-isotope stages (MIS) [Shackleton et al., 1990; Lisiecki, Raymo, 2005].

The similarity in variations in the MS records and other palaeoclimate proxies (ratio of oxygen isotopes, organic carbon, biogenic silica) in the same age rocks confirms the possibility of palaeoclimatic reconstruction using magnetic properties of marine and lake sediments, but also of subaerial deposits
[Evans, Heller, 2001, 2003]. Palaeosol types and pollen assemblages in these sediments are other important proxies for this purpose. Thus, rock magnetic (magnetic properties of rocks) and palaeomagnetic (magnetostratigraphy) methods, especially combined with lithological-palaeopedological and pollen studies, is a powerful tool for the reconstruction of palaeoenvironmental changes, as well as in applied sciences: engineering geology, economics, archaeology, modern environmental and forecasting tasks [Evans, Heller, 2001, 2003; Maher, 2011; Menshov, 2019; Jordanova, Jordanova, 2021; Zeeden, Hambach, 2021 and others].

In this paper, we present methods and directions for our investigation and new results on magnetic susceptibility from loesspalaeosol deposits in the northern, central and southern parts of Ukraine, carried out in the framework of National Research Foundation of Ukraine' project 2020.02/0406 'Magnetic proxies of palaeoclimatic changes in the loess-palaeosol sequences of Ukraine'. At present, the three most complete loess-palaeosol sequences of the Dnieper River basin (Stari Kaydaky and Vyazivok) and the Black Sea Lowland (Roksolany) are compared by magnetic, palaeosol and pollen proxies and correlated with the marine isotope record.

The Ukrainian loess belt: short overview of the previous studies. Loess-soil deposits, covering over $70 \%$ of the territory of Ukraine, are prominent in their stratigraphic completeness. They form the Ukrainian loess belt located in the central part of the Eastern Europe (Fig. 1). Their pedostratigraphy and palaeoenvironmetal proxies (palaeosols and pollen) have been studied by Ukrainian scientists since the 1920s [Krokos, 1926; Veklitch et al., 1967, 1979, 1984, 1993; Veklitch, 1968, 1982; Sirenko, Turlo, 1986; Gozhik et al., 1995, 2000, 2001, 2007; Gozhik, Gerasimenko, 2011; Gozhik, 2012; Bogucki, 1986; Boguckyj, Łanczont, 2002; Boguckyj et al., 2009; Bogucki et al., 2013, 2014; Matviishina et al., 2001; Matviishyna et al., 2010; Matviishyna, Doroshkevych, 2019; Gerasimenko, 2001, 2004, 2006, 2020; Gerasimenko, Matvijishyna, 2007; Sirenko, 2017a,b, 2019a,b; Do- 
roshkevych, 2018; Karmazinenko, 2019; Veklych, 2019; Bonchkovskyi, 2019, 2020a,b and many others]. The significant input has been also made by researchers from other European countries [Velichko, 1997; Bolikhovskaya, Molodkov, 2006; Rousseau et al., 2001, 2011; Haesaerts et al., 2003, 2016, 2019; Lindner et al., 2006; Łanczont, Boguckyj, 2007; Łanczont, Madeyska, 2015; Łanczont et al., 2019; Buggle et al., 2008, 2009; Bokhorst et al., 2009; Veres et al., 2018; Tecsa et al., 2020].

The Stratigraphic framework of the Quaternary deposits of Ukraine [Veklitch et al., 1993], modified in recent two decades [Gozhik et al., 2001; Gerasimenko, 2004, 2006; Matviishyna et al., 2010] and the Stratigraphic Code [Gozhik, 2012] are the main tool for stratigraphical division of the Quaternary deposits in Ukraine. The multidisciplinary palaeogeographical approach was used as the base to substantiate the framework which in- cludes the following methods of palaeoenvironmental studies: lithology, palaeopedology (including micromorphology), clay mineralogy, palaeogeomorphology, mammal fauna, mollusc fauna, pollen, cryolithology, luminescence and radiocarbon dating, palaeomagnetism, and, finally, palaeoclimatology and palaeolandscapes. It should be mentioned that many luminescence and radiocarbon dating results remain contradictory.

The study of the magnetic properties of these rocks began in the 1970s [Tretyak, Volok, 1976; Tretyak, 1980, 1983; Tretyak et al., 1987, 1989; Tretyak, Vigilyanskaya, 1994] and have been continued during the last 20 years [Vigilyanskaya, Tretyak, 2001, 2002; Bakhmutov et al., 2005, 2017; Bakhmutov, Hlavatskyi, 2014; Bakhmutov, Glavatskiy, 2016; Hlavatskyi et al., 2016a,b; Hlavatskyi, 2019; Hlavatskyi, Bakhmutov, 2019, 2020; Nawrocki et al., 1999, 2002, 2016; Gendler

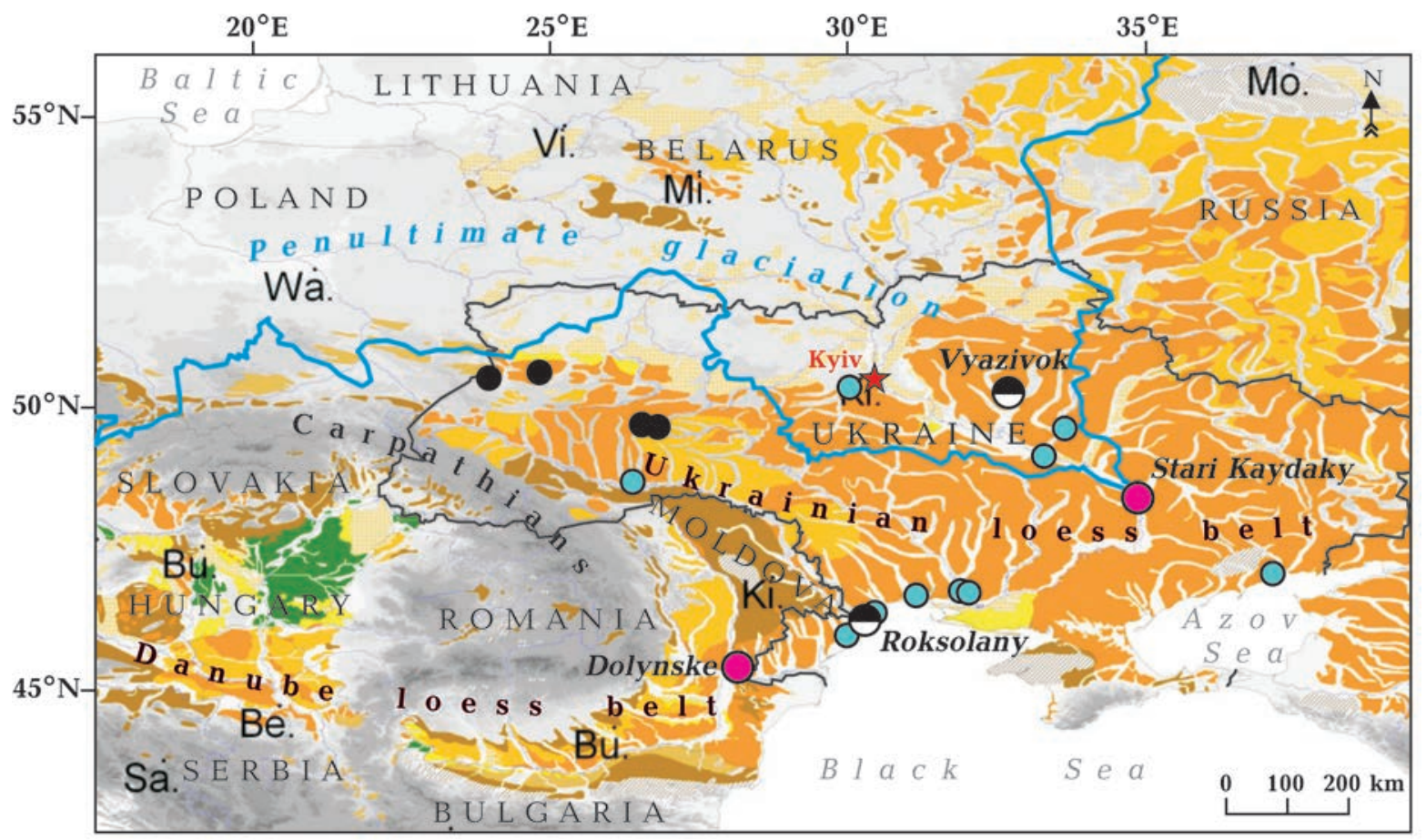

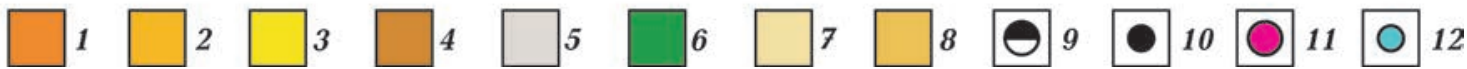

Fig. 1. Map of loess deposits in Central-Eastern Europe [Haase et al., 2007]. Loess distribution (facies): 1 loess, $>5 \mathrm{~m} ; 2$ - loess, $<2$ m; 3 - sandy loess; 4 - loess derivates; 5 - loess and loess derivates in fragmentary distribution; 6 - alluvial loess; 7 - aeolian sand; 8 - loess thickness not differentiated. Selected Ukrainian loess sections: 9 - in which the MBB was detected by co-authors of the present study [Bakhmutov, Hlavatskyi, 2014; Hlavatskyi et al., 2016b; Bakhmutov et al., 2017; Hlavatskyi, Bakhmutov, 2019, 2020]; 10 — other loess sections, studied palaeomagnetically by [Hlavatskyi et al., 2016a, 2021b; Bakhmutov et al., 2017]; 11 — loess sections currently under investigation; 12 - promising research sites, declared within the framework of the Project. The extent of the penultimate glaciation according to [Ehlers et al., 2011]. 
et al., 2006; Boguckyi et al., 2009; Bogucki et al., 2013; Menshov, 2015; Bondar, Ridush, 2015; Bondar et al., 2019]. The results of early research, due to the lack of accurate magnetometers and some methodological issues, in many cases led to misinterpretations. An illustrative example is the contradiction in the definition of the Matuyama-Brunhes boundary (MBB) in the Roksolany section by different scientific teams (discussed in [Hlavatskyi, Bakhmutov, 2020]).

Due to the absence of reliable magnetic (and geochronological) markers for chronostratigraphic subdivision of loess-palaeosol sections in Ukraine, the problems of regional (and global) correlation appear. A lack of reliable geochronometric markers in the reference sections of different regions of Ukraine makes serious difficulties in the synthesis of the palaeoclimatic information. The publications on palaeoclimate and palaeoenvironmental changes in Eurasia demonstrate insufficient study of Eastern Europe, and, in particular, its central part - Ukraine. A lack of reliable geochronometric data from this region, where many stratigraphically complete Quaternary sequences are located, limits the reliability of spatial palaeoclimatic reconstructions and climate change models. Thus, an amplification of chronostratigraphy of the loess-palaeosol sequence in Ukraine and its correlation with global framework, based on updated magnetostratigraphic data, is one of the urgent problems in the present-day study of regional palaeoenvironmental change.

Studied sites. The Vyazivok section is located on the western bank of the Sula River, a tributary of the Dnieper ( $\left.49^{\circ} 57^{\prime} \mathrm{N} ; 32^{\circ} 57^{\prime} \mathrm{E}\right)$, in the Vyazivok village of the Lubny region (see Fig. 1). It is the most stratigraphically complete section in the Dnieper Lowland [Veklitch et al., 1967; Veklitch, 1968, 1982; Matviishina et al., 2001; Rousseau et al., 2001]. This section is $59 \mathrm{~m}$ thick and includes well developed pedocomplexes which alternate with thick loess units. The new results of rock magnetic studies and the stratigraphic positioning of the MBB were presented recently in [Hlavatskyi et al., 2016b; Hlavatskyi, Bakhmutov, 2020]. The MBB has been detected at the depth of
$56.2 \mathrm{~m}$ within the Lower Shyrokyne palaeosol ' $\mathrm{sh}_{1}$ ' (according to stratigraphic subdivision of [Veklitch, 1982; Matviishina et al., 2001]).

The Stari Kaydaky section $\left(48^{\circ} 22^{\prime}\right.$ N, $35^{\circ} 07^{\prime}$ E) is located in the Stari Kaydaky village, near the Dnipro City airport, on the right bank of the Dnieper River (see Fig. 1). In this site, regarded as the main reference section of the Pleistocene in Ukraine, all stratigraphical units of the Ukrainian Quaternary framework have been studied [Veklitch, Sirenko, 1972] in several sections (the integrated thickness of the sequence is $59 \mathrm{~m}$ ). The pedostratigraphical and palaeoenvironmental study of the upper $18.5 \mathrm{~m}$ of one of the sections, including the correlation of the MS curve with those from the Mircea Voda (Romania) and Batajnica/Stari Slankamen (Serbia) sites, and with the marine isotope record, was provided by [Buggle et al., 2008, 2009]. According to this correlation, the first palaeosol (SK-L1S1) corresponds to MIS 3, the second double palaeosol (SK-S1S1 and SK-S1S2) to MIS 5, the third palaeosol (SK-S2) to MIS 7, the fourth (SK-S3) to MIS 9. The fifth palaeosol (SK-S4) was regarded as a truncated pedocomplex being correlated with MIS 11. The lowermost studied double palaeosol (SK-S5) has been equated to MIS 13-15. Two erosional events represented by the truncated soils have been documented within Upper Middle Pleistocene deposits.

In this study, for palaeomagnetic and rock magnetic analysis, the samples were taken in the depth interval of 17.5-28.2 m, with particular attention to lowermost layers, in which the MBB was expected. Thus, we have adopted MS curve of the upper part of the section [Buggle et al., 2009] and have added the new results from the lower units. We continue to follow stratigraphic nomenclature proposed by [Buggle et al., 2008, 2009] (also using the Ukrainian stratigraphical framework), but different interpretation has been suggested for the lowermost beds of the Buggle et al. excavation (see chapter 'Results').

The Roksolany section is located on the coast of the Dniester estuary west of the Roksolany village ( $46^{\circ} 11^{\prime} \mathrm{N} ; 30^{\circ} 26^{\prime} \mathrm{E}$; Fig. 1$)$. This section is one of the most representative 
exposures of the Pleistocene loess series in the Black Sea Lowland (approximately $55 \mathrm{~m}$ thick). The stratigraphy of the Roksolany section and the position of the MBB was a matter of debate for a long time (for a comprehensive overview, see [Hlavatskyi, Bakhmutov, 2020]). Our initial palaeomagnetic studies of the Roksolany profile (Bakhmutov, Hlavatskyi, 2014; Bakhmutov et al., 2017; Hlavatskyi, Bakhmutov, 2019) revealed that the MBB is located at a depth of $46.6 \mathrm{~m}$ between two soils, which were stratified by [Gozhik et al., 1995, 2000, 2007; Bogucki et al., 2013; Łanczont, Madeyska, 2015; Nawrocki et al., 2018] as the Lubny (MIS 13-15) and Martonosha (MIS 17-19) units. Anarrow zone of reversed polarity was also established at 42.0 — $42.5 \mathrm{~m}$ depth in the uppermost part of the Zavadivka soil. In our recent study [Hlavatskyi, Bakhmutov, 2020], we have proposed a new chronostratigraphic model following the Chinese loess designation system, supported by magnetic susceptibility variations, magnetostratigraphic markers, compiled existing radiocarbon and optically luminescence dates, local and regional sedimentological and palaeosol proxies. The Lubny soil, in the lower part of which the Matuyama-Brunhes reversal was detected, has been reinterpreted as the correlative of the Shyrokyne (R-S7) unit. The reversed polarity zone above, in the interpretation of [Hlavatskyi, Bakhmutov, 2020], represents Stage 17 excursion (at $670 \mathrm{ka}$ ), indicating the end of the Martonosha (R-S6, MIS 17) stage. For establishing the chronostratigraphy for the Roksolany section, the stratigraphy of the key locality of the loess-palaeosol sequence at Vyazivok was used as a corner stone.

Sampling strategy and rock magnetic methods. Field works include detailed lithological and pedostratigraphic description of outcrops, in particular, of facial changes of rocks. The representative collections of samples have been taken from the above mentioned three sections by following strategy: 1) with a sampling density of about every 2-10 cm - 150 specimens from the Stari Kaydaky section below the $17.5 \mathrm{~m}$ depth (taken as a pilot collection); 2) with a sampling density of about every $2-15 \mathrm{~cm}-$ from the
Vyazivok section (from 6 continuous exposures) - 750 specimens; 3) with a sampling density of about every $2-15 \mathrm{~cm}$ - more than 800 specimens from the Roksolany section (whole section represented by 9 overlapping exposures). For palaeomagnetic measurements, standard oriented cylinders $(2.2 \mathrm{~cm}$ in length and $2.5 \mathrm{~cm}$ in diameter) and cubes $(2.0 \mathrm{~cm}$ side) were cut while for rock magnetic experiments non-oriented specimens (each weighing about 10-15 g) were taking more densely. In addition, for each section the sampling has been made 1) for palaeopedological study (50 g) — from each lithological type of rocks and genetic horizons of palaeosols; 2) for pollen study (200 g) — with interval of every $10 \mathrm{~cm}$ and $10 \mathrm{~cm}$ in depth from the excavation wall.

The enviromagnetic parameters commonly accepted in rock magnetic investigations of the loess-soil deposits [Evans, Heller, 2003; Matasova, Kazansky, 2004], and used in our study, are given in Table 1. The analysis of these parameters allows to determine: mineralogical and granulometric changes in rocks associated with different sources of aeolian material, chemical and biogenic processes; concentration, size and domain state of magnetic grains in rocks, origin of the magnetization of rocks (terrigenous, chemogenic, biogenic magnetic minerals); type of recording of magnetic susceptibility in different provinces of pedosedimentogenesis; directions of palaeowinds; identification of magnetic minerals and carriers of normal remanent magnetization (NRM). The latter is a necessary component of palaeomagnetic studies; the directions of the NRM components allow specifying magnetostratigraphic markers and performing independent correlation and dating of the loess-palaeosol sequences.

Measurements of magnetic parameters, their ratios and plots are performed according to commonly accepted methods represented by [Butler, 1992; Evans, Heller, 2003].

In this study, specimens were thermally demagnetized using a MMTD 80 furnace up to $270-300{ }^{\circ} \mathrm{C}$. Specimens from the SKS6S3 and SK-S7S1 soil units at Stari Kaydaky have been thermally demagnetized up 
to $500{ }^{\circ} \mathrm{C}$. The residual field in the furnace was less $10 \mathrm{nT}$. After each heating step, bulk susceptibility $(\kappa)$ at room temperature was measured to monitor possible mineralogical changes. Duplicate specimens were subjected to alternating field (AF) demagnetization

\section{Ta b le 1. Common rock magnetic parameters and their bivariate ratios}

\begin{tabular}{|c|c|c|}
\hline Symbol & $\begin{array}{l}\text { Magnetic } \\
\text { quantities }\end{array}$ & Description \\
\hline \multicolumn{3}{|c|}{$\begin{array}{l}\text { Group 1. Represents the concentration of magnetic minerals } \\
\text { (concentration-sensitive or concentration-dependent) }\end{array}$} \\
\hline$\kappa$ & $10^{-6} \mathrm{SI}$ & $\begin{array}{c}\text { Volume magnetic susceptibility (dimensionless): subject to a small } \\
\text { amount of superparamagnetic (SP) particles }\end{array}$ \\
\hline$\chi$ & $\mathrm{m}^{3} / \mathrm{kg}$ & Mass-specific magnetic susceptibility \\
\hline$\chi_{\text {ferri }}$ & $\mathrm{m}^{3} / \mathrm{kg}$ & Ferrimagnetic susceptibility \\
\hline $\mathrm{M}_{\mathrm{s}}$ or $\mathrm{M}_{\mathrm{s}}$ & $\mathrm{Am}^{2} / \mathrm{kg}$ & Saturation magnetization (mass normalized) \\
\hline $\mathrm{M}_{\mathrm{rs}}$ or $\mathrm{J}_{\mathrm{rs}}$ & $\mathrm{Am}^{2} / \mathrm{kg}$ & Saturation remanent magnetization (SIRM) \\
\hline $\mathrm{M}_{\mathrm{i}}$ or $\mathrm{J}_{\mathrm{i}}$ & $\mathrm{Am}^{2} / \mathrm{kg}$ & Isothermal remanent magnetization (IRM) \\
\hline $\mathrm{M}_{\text {ri }}$ or $\mathrm{J}_{\text {ri }}$ & $\mathrm{Am}^{2} / \mathrm{kg}$ & $\begin{array}{c}\text { Anhysteretic remanent magnetization (ARM): subject to a small amount } \\
\text { of single domain particles }\end{array}$ \\
\hline$M_{n}$ or $J_{n}$ & $\mathrm{~mA} / \mathrm{m}$ & $\begin{array}{l}\text { Natural remanent magnetization (NRM): subject to the constant compo- } \\
\text { sition of the magnetic fraction }\end{array}$ \\
\hline \multicolumn{3}{|c|}{ Group 2. Composition of the magnetic fraction (relative content in the magnetic fraction) } \\
\hline Q-ratio & - & Koenigsberger ratio \\
\hline S-ratio & - & $\begin{array}{l}\text { Relative amounts of high coercivity («hard», like magnetite/maghemite) } \\
\text { to low coercivity («soft», like goethite/hematite) remanence }\end{array}$ \\
\hline $\mathrm{H}_{\mathrm{s}}$ & $\mathrm{mT}$ & $\begin{array}{c}\text { Saturation field or field, in which } 90 \% \\
\text { of the saturation magnetization is acquired }\end{array}$ \\
\hline $\mathrm{B}_{\mathrm{C}}$ or $\mathrm{H}_{\mathrm{C}}$ & $\mathrm{mT}$ & Coercive force \\
\hline $\mathrm{B}_{\mathrm{cr}}$ or $\mathrm{H}_{\mathrm{cr}}$ & $\mathrm{mT}$ & Remanence coercivity \\
\hline \multicolumn{3}{|c|}{$\begin{array}{l}\left.\text { Curie temperatures } \mathrm{T}_{\mathrm{c}}\left(\text { by } \chi(\mathrm{T}), \mathrm{M}_{\mathrm{s}}(\mathrm{T})\right) \text {; unblocking temperatures } \mathrm{T}_{\mathrm{ub}} \text { (by SIRM }(\mathrm{T}), \mathrm{NRM}(\mathrm{T})\right) \text {; median de- } \\
\text { structive } \mathrm{AF} \text { field } \mathrm{MDF}(\text { by AF demagnetization of remanent magnetization NRM, SIRM, ARM), residual } \\
\text { magnetization after maximum demagnetization } \mathrm{M} / \mathrm{M}_{\text {max }} \text { hard isothermal remanent magnetization HIRM }\end{array}$} \\
\hline \multicolumn{3}{|c|}{$\begin{array}{c}\text { Group 3. Particle size of magnetic minerals and the associated domain state of ferromagnetic } \\
\text { (structurally sensitive) }\end{array}$} \\
\hline FD\%-ratio & & Frequency-dependent factor; FD\% $=100 \times\left(\chi_{\text {lf }}-\chi_{\mathrm{hf}}\right) / \chi_{\mathrm{lf}}$ \\
\hline $\mathrm{M}_{\mathrm{ri}}$ or $\mathrm{J}_{\mathrm{ri}}$ & $\mathrm{Am}^{2} / \mathrm{kg}$ & $\begin{array}{c}\text { Anhysteretic remanent magnetization (ARM): subject to a small amount } \\
\text { of single domain particles }\end{array}$ \\
\hline \multicolumn{3}{|c|}{$\begin{array}{l}\text { Ratios } \chi / \text { SIRM, } \chi / \text { ARM, SIRM/ARM (proportional to the grain size); bivariate plots of hysteresis parameters } \\
\qquad M_{\mathrm{rS}} / \mathrm{M}_{\mathrm{S}^{\prime}} \mathrm{B}_{\mathrm{Cr}} / \mathrm{B}_{\mathrm{C}}\end{array}$} \\
\hline \multicolumn{3}{|c|}{ Group 4. Anisotropy of magnetic susceptibility (AMS; quantitative parameters) } \\
\hline L & - & Degree of magnetic lineation \\
\hline $\mathrm{F}$ & - & Degree of magnetic foliation \\
\hline $\mathrm{P}$ & - & Degree of anisotropy \\
\hline $\mathrm{T}$ & - & Shape parameter of AMS ellipsoid \\
\hline \multicolumn{3}{|c|}{ Directions of maximum $\left(\mathrm{K}_{1}\right)$, intermediate $\left(\mathrm{K}_{2}\right)$, and minimum $\left(\mathrm{K}_{3}\right)$ axis of AMS ellipsoid } \\
\hline \multicolumn{3}{|c|}{$\begin{array}{l}\text { Group 5. Represents the contribution of paramagnetic minerals to magnetic properties } \\
\text { (by minor concentrations of ferromagnetic, such a contribution can be significant) }\end{array}$} \\
\hline $\mathrm{M}_{\max }$ or $\mathrm{J}_{\max }$ & $\mathrm{mA} / \mathrm{m}$ & Maximum of magnetization (by $1.5 \mathrm{~T}$ ) \\
\hline $\mathrm{M}_{\mathrm{par}}$ or $\mathrm{J}_{\mathrm{par}}$ & $\mathrm{mA} / \mathrm{m}$ & Magnetization of paramagnetic minerals $\left(\mathrm{M}_{\max }-\mathrm{M}_{\mathrm{s}}\right)$ \\
\hline$\chi_{\text {par }}$ & $\mathrm{m}^{3} / \mathrm{kg}$ & Paramagnetic susceptibility \\
\hline$\chi_{\mathrm{sp}}$ & $\mathrm{m}^{3} / \mathrm{kg}$ & Superparamagnetic susceptibility \\
\hline
\end{tabular}


with steps 5-20 mT up to 60-100 mT using a LDA-3A demagnetizer. Remanent magnetization of specimens was measured by JR-6 spinner magnetometer. Measurements of mass-specific magnetic susceptibility $(\chi)$ were carried out using by MFK1-FB Kappabridge. The equipment is placed in a non-magnetic room MMLFC, which eliminates the effect of remagnetization of samples by viscosity. The data (multicomponent analysis of NRM and separation of characteristic (ChRM) components) were proceeded by Remasoft 3.0 software [Chadima, Hrouda, 2006].

Palaeopedological descriptions and interpretations in the new excavations at Vyazivok and Stari Kaydaky followed the methodology by [Veklitch et al., 1979; Gerasimenko, 2020]. Individual palaeosols were described within pedocomplexes, and if the welded soils occurred in a studied section, additional excavations were entertained in order to trace a palaeopedocatena and to reveal the well-developed pedocomplex of the corresponding soil unit. To define soil types of palaeosols, the following features of them have been studied: genetic soil horizons, color, thickness, grain-size characteristics, soil structure, forms of carbonate calcium, iron and manganese (if available), biological elements of a profile, types of soil boundaries, palaeocryogenic forms. The primary and secondary (diagenetic) features were distinguished.

Pollen samples were taken each 5-10 cm from the Upper Pleistocene deposits at Vyazivok and from each soil genetic horizon from the Upper and Middle Pleistocene deposits at Stari Kaydaky. The sample processing has followed the technique [Malyasova, Spiridonova, 1989] which includes boiling of a $100 \mathrm{~g}$ sample in $10 \%$ solution of $\mathrm{HCl}$ in order to remove carbonates, in $25 \%$ solution of sodium pyrophosphate in order to remove clay fraction. Then the secondary carbonates have been removed by boiling in $10 \%$ solution of $\mathrm{HCl}$ again, and organic matter was dissolved in $10 \%$ solution of $\mathrm{KOH}$. All steps were separated by decanting of a sample in distilled water to the neutral reaction of a solution. The next step was a separation in heavy liquid ( $\mathrm{CdI}_{2}$ and $\left.\mathrm{KI}\right)$ of specific gravity
2.2. If a sample included many sand grains, in addition to the described technique, cold treatment with $10 \%$ solution of HF has been applied for at least 18 hours.

Results and interpretation. The results from the Vyazivok and Roksolany sections were published (or partly published) earlier [Matviishina et al., 2001; Rousseau et al., 2001; Gerasimenko, Matvijishyna, 2007; Haesaerts et al., 2016; Hlavatskyi, Bakhmutov, 2020]. Here, we provide the results of the new pedostratigraphical and rock magnetic studies of the lower part of the excavation at Stari Kaydaky which upper part was described in [Buggle et al., 2008, 2009].

Litho- and pedostratigraphy. In order to make connection between the upper and lower sequences at the Stari Kaydaky site, the short description of the Upper Pleistocene and the Upper Middle Pleistocene pedocomplexes are given, as well as their correlation with the Middle Danube loess nomenclature [Buggle et al., 2008, 2009].

The uppermost palaeosol is related to $\mathrm{Vy}$ tachiv unit ('vt') and correlated with SK-L1S1 (MIS 3). In the southern wall of the excavation it is a welded soil but in its western wall, Vytachiv pedocomplex consists of two thin Calcaric Cambisols, light-brown, enriched in coarse silt, non-compacted, without welldeveloped structure, with pure white farinaceous-carbonate horizon in the subsoils. These soils are separated by a thin loess bed $\left(' \mathrm{vt}_{2}\right.$ ') and underlain by a thin Uday loess ('ud'/SK-L1L2, MIS 4).

Below, there is a thick pedocomplex consisting of three palaeosols. From the top to bottom, they are two Chernozems and a thick Luvisol. The Chernozems are dark-grey, enriched in fine silt, slightly compacted, crumbly, primarily leached from carbonates, and they are separated by a thin loess-like bed. The similar bed separates the lower Chernozem from the Luvisol. The latter has a very distinct differentiation of the soil profile into grey A horizon, pure white loose E horizon, and bright-brown Bt horizon, strongly compacted clayey silt, with blocky-prismatic structure, and a sharp boundary with the underlying thick loess. This pedocomplex has 
all typical features of the Pryluky-Kaydaky palaeosol succession (' $\mathrm{pl}-\mathrm{kd}$ ') which is correlated with MIS 5 [Rousseau et al., 2001; Gerasimenko, 2001; Haesaerts et al., 2016]. At this excavation, the Pryluky Chernozem has been correlated with SK-S1S1 (MIS 5a-c) and Kaydaky Luvisol with SK-S1S2 (MIS 5e) [Buggle et al., 2008, 2009]. The underlying typical loess, composed by coarse silt - the Dnipro loess ('dn'/SK-L2, MIS 6) - reaches $5 \mathrm{~m}$ in thickness in the southern wall.

The Potyagaylivka pedocomplex ('pt') is partly eroded from the top. The two upper soils are truncated, and only the lower soil is represented by a Cambisol, with well differentiated soil profile (dark-grey A horizon and bright-brown B horizon, both clayey silty, crumbly-prismatic, with distinct biological boundaries). This pedocomplex is correlated with MIS 7, the individual soils with SK-S2S1, SK-S2S2 and SK-S2S3, respectively [Buggle et al., 2008, 2009]. The underlying thin palebrown loess-like bed (SK-L3, MIS 8) separates SK-S2 from the SK-S3 pedocomplex. Cryogenic fissures, connected with a cold climate of MIS 8, strongly disturbed the Upper Zavadivka pedocomplex (' $\left.\mathrm{Zv}_{3}{ }^{\prime}\right)$.

The Upper Zavadivka soil succession (SKS3) consists of the well developed pedocomplex from Chernozem ' $\mathrm{Zv}_{3 \mathrm{~b} 2}$ ' (SK-S3S1) and Greyzemic Luvisol ' $\mathrm{Zv}_{3 \mathrm{~b} 1}$ ' (SK-S3S2), and from a thin Luvic Cambisol ' $\mathrm{Zv}_{3 a}$ ' (SK-S3S3), separated from the pedocomplex by a thin loess bed. All palaeosols are compacted (particularly Bth and Bt horizons of Greyzemic Luvisol) and composed by clayey silt. The Chernozem is dark-grey, with multiple krotovinas and frost fissures from above, both filled with loess; the transition downward is gradual. The Bth and Bt horizons of Greyzemic Luvisol are darkbrown and brown, respectively, with strong blocky-prismatic structure, with glossy clay cutans on the ped surfaces; transition downward is gradual. The Luvic Cambisol ' $\mathrm{zv}_{3 \mathrm{a}}$ ' might be truncated, as its upper boundary is rather sharp. Then only the reddish-brown Bw horizon of this soil is present in the section. This subunit has been formerly considered as the truncated Lower Zavadivka (' $\mathrm{Zv}_{1}{ }^{\prime} / \mathrm{SK}$ S4, MIS 11) [Buggle et al., 2008, 2009]. It is underlain by a thin loess, related to the ' $\mathrm{zv}_{2}$ ' unit (SK-L4, MIS 10). In palaeodepressions, the ' $\mathrm{zv}_{3 \mathrm{~b} 2}$ ' Chernozem is overlain by a thin bed of dark-brown pedosediments ' $\mathrm{Zv}_{3 \mathrm{c}}$ ', with many carbonate rootlets and sharp erosional boundaries.

Below in the section, there is a thick soil unit of a complex structure (now preliminarily regarded as Lower Zavadivka, SK-S4). It includes (from the top to bottom): a weakly developed Haplic Phaeozem 'zv ${ }_{1 \mathrm{c}}$ ' (SK-S4S1), underlain by a thin loess-like bed, two thick Colluvic Luvisols ( ' $\mathrm{Zv}_{1 \mathrm{~b} 2}$ '/SK-S4S2 and ' $\mathrm{zv}_{1 \mathrm{~b} 1}$ '/ SK-S4S3), separated by a thin non-soil bed, filled with white carbonates, and underlain by a thin loess-like bed, and a very thin Cambisol ' $\mathrm{zv}_{1 \mathrm{a}}$ ' (SK-S4S4). The Haplic Phaeozem has a dark-grey A horizon, pale $\mathrm{AB}$ horizon, and light-brown B horizon. The soil contains much less clay particles than the overlying and underlying soils. It has less compacted material (with crumbly structure) and gradual boundaries; primarily it was leached from carbonates. The two Colluvic Luvisols have reddish-brown colour, particularly bright in the lower soil. They are enriched in clay fractions but do not have a distinct structure (probably because of some input of colluvial silt material). The upper soil was primarily leached from carbonates - many soft carbonate nodules, representing the $\mathrm{Ck}$ horizon of the ' $\mathrm{zv}_{1 \mathrm{~b} 2}$ ' soil, occur in the material of the soil ' $\mathrm{Zv}_{1 \mathrm{~b} 1}$ ' and in the underlying loess-like loam. The Phaeozem ' $\mathrm{zv}_{1 \mathrm{c}}$ ' and the very top of the ' $\mathrm{zv}_{1 \mathrm{~b} 2}$ ' soil were formerly regarded as the Lubny unit (SK-S5, MIS 13-15) [Buggle et al., 2008, 2009]. Luvisols are typical for Lower Zavadivka in the northern part of Ukraine, whereas Chromic Luvisols are characteristic of this unit in the southern part of Ukraine.

Below the loess-like bed (SK-L5, Tyligul unit?), underlying the described pedocomplex, there is a soil unit (SK-S5), consisting of two pedocomplexes, with completely different types of palaeosols than in SK-S4. Its upper pedocomplex includes a Chernozem (SK-S5S1), dark brownish-grey, clayey, compacted, crumbly-prismatic, leached from carbonates, with several krotovinas, filled with loess, and with gradual boundaries. The lower 
soil is a Luvisol (SK-S5S2) with such genetic horizons: $\mathrm{A} / \mathrm{E}$ - brown, contain less clay particles than the overlying Chernozem; Ewhitish, sandy silt, enriched in $\mathrm{SiO}_{2}$, slightly gleyed, with a sharp lower boundary; Bt bright-brown, sandy clayey, blocky-prismatic, with the gradual lower boundary. The soil succession in the lower pedocomplex (Fig. 2) is similar. The upper soil is clayey Chernozem (SK-S5S3), brownish-grey, compacted, blocky. The lower soil is a Luvisol (SK-S5S4) with such genetic horizons: A — dark-brown, clayey silt, with an admixture of $\mathrm{SiO}_{2}$ and a sharp lower boundary; E - whitish sandy silt, greatly enriched in $\mathrm{SiO}_{2} ; \mathrm{E}-\mathrm{Bt}$ - light-brown, with whitish spots of $\mathrm{SiO}_{2}$ and small silicified nodules of $\mathrm{CaCO}_{3}$ ( $\mathrm{Ck}$ horizon of the overlying soil); Bt - brown, clayey, compacted, prismatic, the lower boundary is sharp. Clayey Chernozems and Luvisols occur both in Lubny ('lb') and Upper Shyrokyne ( ${ }^{(} \mathrm{sh}_{3}$ ') units, but the lower pedocomplex is not enough clayey for the Shyrokyne unit, and Luvisols with such differentiated genetic profile and with abundance of $\mathrm{SiO}_{2}$ are also not typical (even in palaeodepressions) for the Upper Shyrokyne pedocomplex.

On the contrary, the upper palaeosol (SKS6S1) of the underlying soil unit (SK-S6; Fig. 2) is most enriched in clay fraction, has bright reddish-brown colour and prismatic structure, with glossy coatings on ped surfaces. The middle soil (SK-S6S2) of this pedocomplex preserves its A horizon - darkgrey, clayey, with punctuation of manganese hydroxides and secondary carbonates, with the distinct transition to the Btw horizon. The latter is dark-brown, clayey, prismatic, glossy, with manganese and secondary carbonate punctuations. The Bt horizon of the soil is lighter, bright-brown, prismatic, with manganese punctuation, the transition downward is distinct. A very thin bed of loess-like clay separate the SK-S6S2 soil from the lowermost soil of this pedocomplex. The latter (SK-S6S3) includes A horizon (dark-brown, with manganese punctuation) and Btw horizon (light-brown, prismatic, with abundant manganese punctuation); the lower boundary is sharp. The two upper soils of the SK-S6 pedocomplex are very similar to the Mediterranean red-brown soils, which are described as Chromic Cambisols in the mountainous areas of the Mediterranean, but in the accumulative plains, they must be much thicker than common Cambisols. The lowermost soil is a Chromic Luvisol with $\mathrm{E}(\mathrm{gl})$ and Bt horizons. Its development indicates a greater atmospheric and underground moisture during its formation as compared with the overlying palaeosol. The soil types and soil succession of the pedocomplex has a typical feature of the Martonosha ('mr') unit.

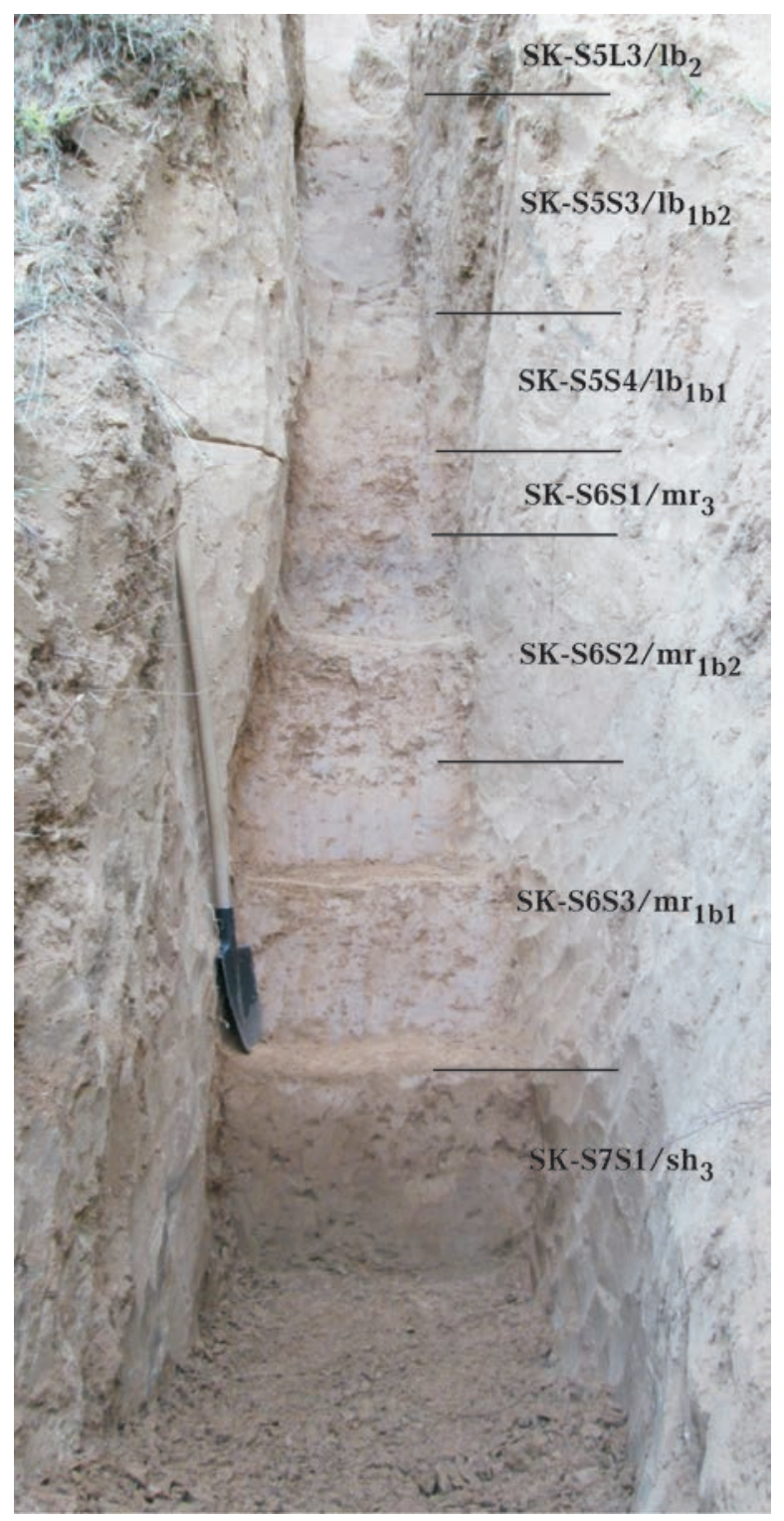

Fig. 2. Field photograph of the lowermost units of the exposure studied at the Stari Kaydaky site. 
The lowermost soil in the section (preliminarily designated as SK-S7S1; Fig. 2) is a Vertisol, which A horizon is exposed - darkbrown, very clayey, the most compacted, has great prismatic peds with slick sides features. Vertisols are most typical for the Shyrokyne unit in Ukraine.

Pollen. The pollen data from the Stari Kaydaky site will be completely presented in the next paper but here we can mention that the Vytachiv soil was formed under boreal steppe environments, whereas the Pryluky Chernozems under south-boreal steppe (few broadleaved trees grew in gullies), and the humus horizon of the Kaydaky soil under the subboreal forest-steppe. The lessivage processes in the Kaydaky times developed under the broad-leaved woodlands. Pollen succession from the larger part of the Luvisol resembles that of the Last Interglacial, with first appearance of elm and oak, then lime and hazel, and, finally, hornbeam. The lower Potyagaylivka soil was formed under forest-steppe of subboreal climate, which was less humid than at Kaydaky times. The Upper Zavadivka Chernozem is a product of steppe vegetation of subboreal climate (broad-leaved trees in gullies), whereas both Luvisols of this unit developed under broad-leaved woodlands. The Greyzemic Phaeozem of the Lower Zavadivka unit was formed under subboreal mesophytic steppe (few broad-leaved trees in gullies), and the upper Colluvic Luvisol under a sparse broad-leaved woodland (the warmth-loving walnut occurred at this time).

Magnetic susceptibility. The variations in the low-frequency magnetic susceptibility $\left(\chi_{\mathrm{lf}}\right)$ values for the composite section are shown in Fig. 3. The changes are highly consistent with the alternation between loess and palaeosol units, with enhanced values in palaeosols, and generally reduced values in loess units. The $\chi_{\mathrm{lf}}$ values in loess range from 7 to $15 \times 10^{-8} \mathrm{~m}^{3} / \mathrm{kg}$. SK-S2, SK-S3 and SK-S4 palaeosols are significantly magnetically enhanced (up to $70 \times 10^{-8} \mathrm{~m}^{3} / \mathrm{kg}$ ) relative to other soils, due to strong pedogenesis. Two samples from well-developed rubified SK-S4 pedocomplex have higher values: 85 and $96 \times 10^{-8} \mathrm{~m}^{3} / \mathrm{kg}$. Measurements of other rock magnetic parameters are currently in progress.

The good correspondence of the MS curve with changes in the marine $\delta^{18} \mathrm{O}$ signal (see Fig. 3), provides a strong evidence for correlating the Pryluky-Kaydaky (SK-S1) pedocomplex at Stari Kaydaky to MIS 5 [Buggle et al., 2008, 2009], as well as that in the Vyazivok section [Rousseau et al., 2001; Hlavatskyi, Bakhmutov, 2020]. The correlation between MS curve of lower palaeosol units and the marine isotope record is rather speculative (see Fig. 3).

The background magnetic susceptibility in the Stari Kaydaky section is similar to that of the Roksolany and Vyazivok sections (5-10) $\times 10^{-8} \mathrm{~m}^{3} / \mathrm{kg}$ (Fig. 4), but is much lower compared to that in the Danube (2-5 times) and Chinese (4-10 times) sequences. This difference indicates a contribution from different dust sources in Ukrainian, Danube and Chinese loess archives.

Magnetostratigraphy. For now, 90 specimens were palaeomagnetically investigated: 48 specimens in the depth interval of 21.5 to $28.2 \mathrm{~m}$ were subjected to thermal demagnetization (up to $300-500^{\circ} \mathrm{C}$ ); and 42 specimens in the depth interval of 17.5 to $25.1 \mathrm{~m}$ were subjected to stepwise AF demagnetization (up to 60-80 mT). Secondary viscous magnetization parallel to the present-day field, or acquired during storage, was removed by heating samples to $240-270{ }^{\circ} \mathrm{C}$. The ChRM components for most samples separated between $240{ }^{\circ} \mathrm{C}$ and $500{ }^{\circ} \mathrm{C}$ (Fig. 5, a), and retain a relatively stable direction up to $500^{\circ} \mathrm{C}$. These stable high temperature components decay with increasing temperature toward the origin along nearly the same trajectory as the medium temperature components (e.g., Fig. 5, a). All samples between 270 and $500{ }^{\circ} \mathrm{C}$, including those from the lowermost part of the SK-S7S1 soil subunit ( ${ }^{\mathrm{s}} \mathrm{h}_{3}{ }^{\prime}$ ), show entirely a normal polarity.

In most specimens after stepwise AF demagnetization, a high-coercitivity component was totally removed only by $60-80 \mathrm{mT}$ field (Fig. 5, b), indicating that hematite is the main ChRM carrier in these samples. The ChRM components also demonstrate the stable 
trajectory towards the origin, indicating the normal polarity of all specimens collected from the SK-S6S2 to SK-S4 unit. However, additional AF demagnetization investigation of the lowermost part of the profile (in $25.1-28.2 \mathrm{~m}$ depth range) is required, and it will be presented in further submissions.
Thus, our palaeomagnetic data indicates that the entire studied part of the section formed during the Brunhes chron, i.e. younger than $780 \mathrm{ka}$.

Discussion. Fig. 4 presents the correlation of the master Ukrainian loess-palaeosol sequences based on the geochronology of the

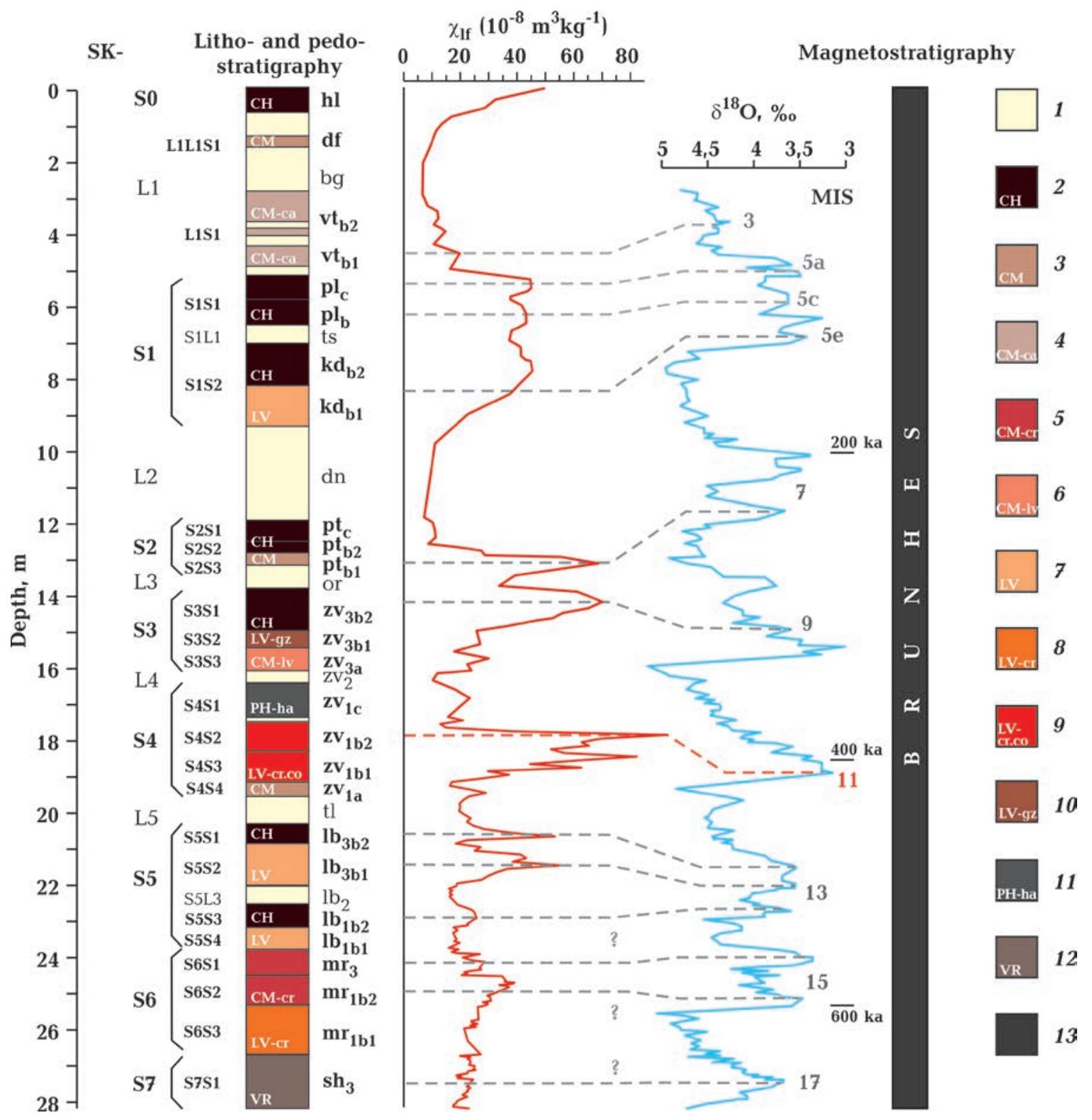

Fig. 3. Revised litho- and pedostratigraphy, magnetic susceptibility $\left(\chi_{\mathrm{lf}}\right)$ curve (in the depth interval of $0-17 \mathrm{~m}$ adopted from [Buggle et al., 2009]), preliminary correlation with the benthic $\delta^{18} \mathrm{O}$ record from ODP site 677 [Shackleton et al., 1990] with reference to marine isotope stages (MIS) [Railsback et al., 2015], and magnetostratigraphic chart of the Stari Kaydaky section. To the left of lithological column the stratigraphic nomenclature modified from [Buggle et al., 2008, 2009] is shown, to the right stratigraphic subdivision following the labelling system of [Veklitch et al., 1993; Gerasimenko, 2004] is proposed by this study. Lithology: 1 - loess. Soil types: 2 - Chernozem $(\mathrm{CH}) ; 3$ - Cambisol (CM); 4 - Calcaric Cambisol (CM-ca); 5- Chromic Cambisol (CM-cr); 6 - Luvic Cambisol (CM-lv); 7 - Luvisol (LV); 8 - Chromic Luvisol (LV-cr); 9 - Chromic Colluvic Luvisol (LV-cr.co); 10 - Greyzemic Luvisol (LV-gz); 11 - Haplic Phaeozem (PH-ha); 12 - Vertisol (VR). Geomagnetic polarity: 13 - normal. 
Roksolany and Vyazivok sites discussed in [Hlavatskyi, Bakhmutov, 2020], and supported by new data from the Stari Kaydaky section introduced in this study. At Stari Kaydaky, the correlation of SK-S1, SK-S2 and SK-S3 palaeosols with MIS 5, MIS 7 and MIS 9, respectively, presented in [Buggle et al., 2008,
2009], is accepted in our paper. The SK-S4 palaeosol at Stari Kaydaky like its equivalents at Stari Slankamen and Batajnica sites, and in the composite profile for Vojvodina [Marković et al., 2015], was assigned to MIS 11 [Buggle et al., 2008, 2009]. According to the new Eurasian stratigraphic scheme adopted in [Sümegi et

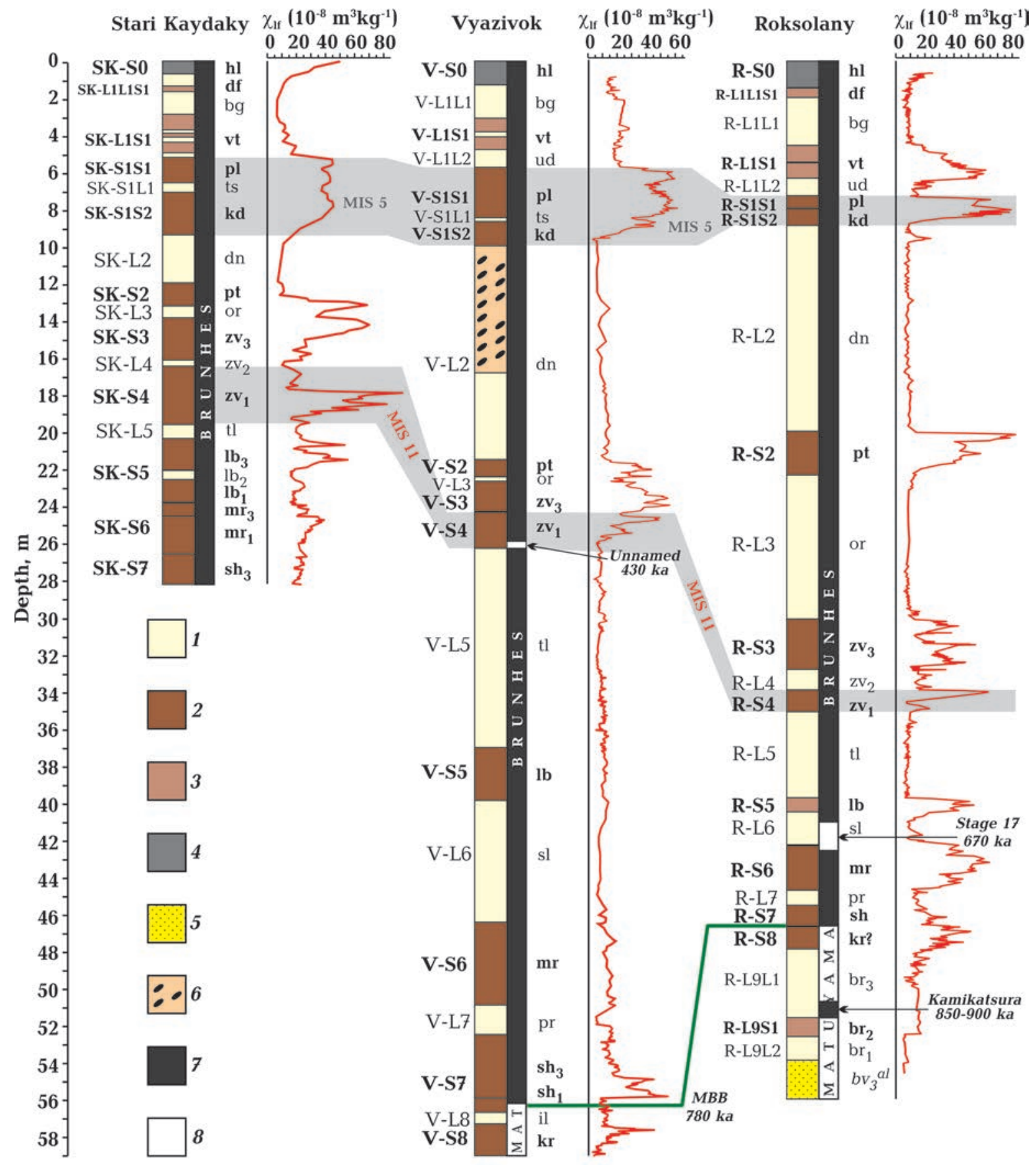

Fig. 4. Correlation chart of the sequences studied resulting from palaeomagnetic and magnetic susceptibility records. Simplified lithology: 1 - loess and loess-like loam; 2 - palaeosol; 3 - embryonic soil; 4 - recent soil; 5 - sand; 6 - glacial till. Geomagnetic polarity: 7 - normal; 8 - reversed. Names of detected geomagnetic excursions are typed by bold italic font. 
al., 2018], both S3 and S4 of the Serbian sites (except Mošorin), Bulgarian and some Romanian sites (e.g., Zimnicea) have been merged into a single pedocomplex representing MIS 9. Based on our record for MIS 9 from Roksolany and Vyazivok, and the similar palaeosol succession patterns at Stari Kaydaky, the former SK-S4 soil unit is now preliminarily related to the lower part of SK-S3. Remarkably, the lower member of this newly designated S3 pedocomplex (formerly marked as S4) has a lower magnetic susceptibility as compared to the upper one. This feature is valid for all Serbian, Romanian and Bulgarian sites [Sümegi et al., 2018]. On the contrary, the lower pedomember of the S3 pedocomplex at Roksolany and Vyazivok represented by two soils of climatic optima (' $\mathrm{Zv}_{3 \mathrm{~b} 1}$ ' and ' $\mathrm{Zv}_{3 \mathrm{~b} 2}$ '), is characterized by the specific double peaks (see Fig. 4), which most likely correspond to marine isotope substages $9 \mathrm{c}-\mathrm{e}$.

The well-developed Colluvic Luvisols, pre-

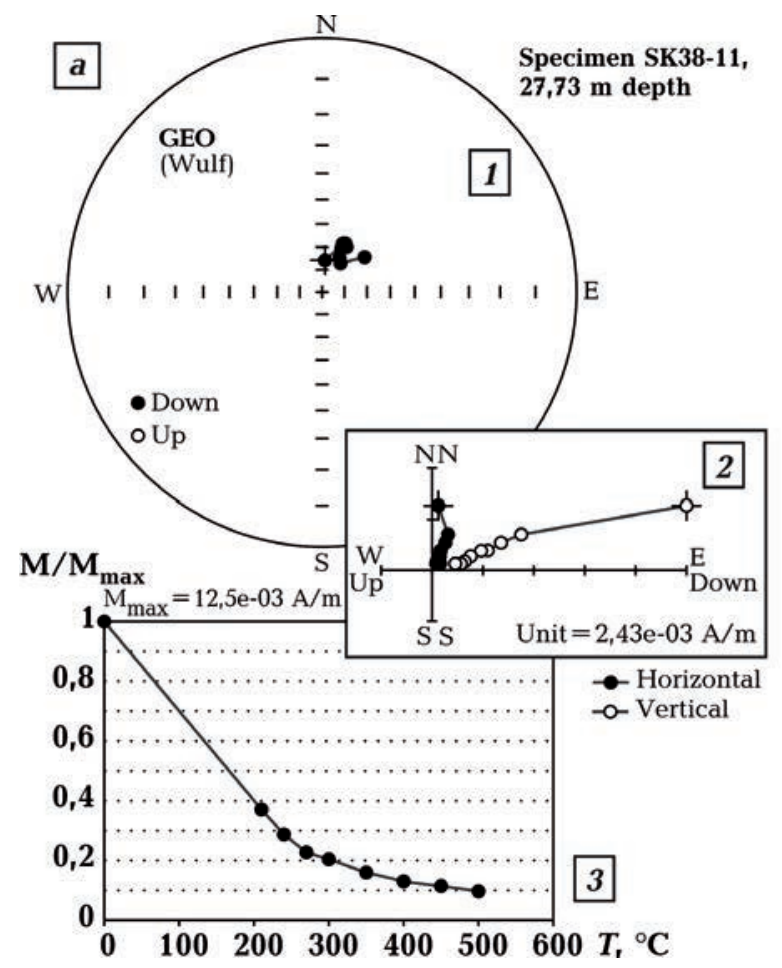

viously regarded as the SK-S5 unit and correlated with MIS 13-15 [Buggle et al., 2008, 2009], are preliminarily compared now with SK-S4 unit. The latter corresponds to one of the warmest and longest interglacials of the past $800 \mathrm{ka}$, the MIS 11 [Shackleton et al., 1990; Lisiecki, Raymo, 2005; Head, Gibbard, 2015; Sümegi et al., 2018 and references therein]. In Chinese loess-palaeosol sequences a strong MIS 13 interglacial is hallmarked by a well-developed S5S1 pedocomplex [Lu et al., 2018] because of an enhanced East-Asian Summer Monsoon bringing more precipitation [An et al., 1987; Clemens et al., 2008; Guo et al., 2009]. In Europe, in contrast to Eastern Asia, the higher degree of pedogenesis development and, particularly, rubification is recorded in MIS 11 pedocomplexes [Sümegi et al., 2018; Bradák et al., 2019]. Besides, the regional diversity in the intensity of the S5S1 soil formation exists also in China. For instance, as opposite to the central and eastern

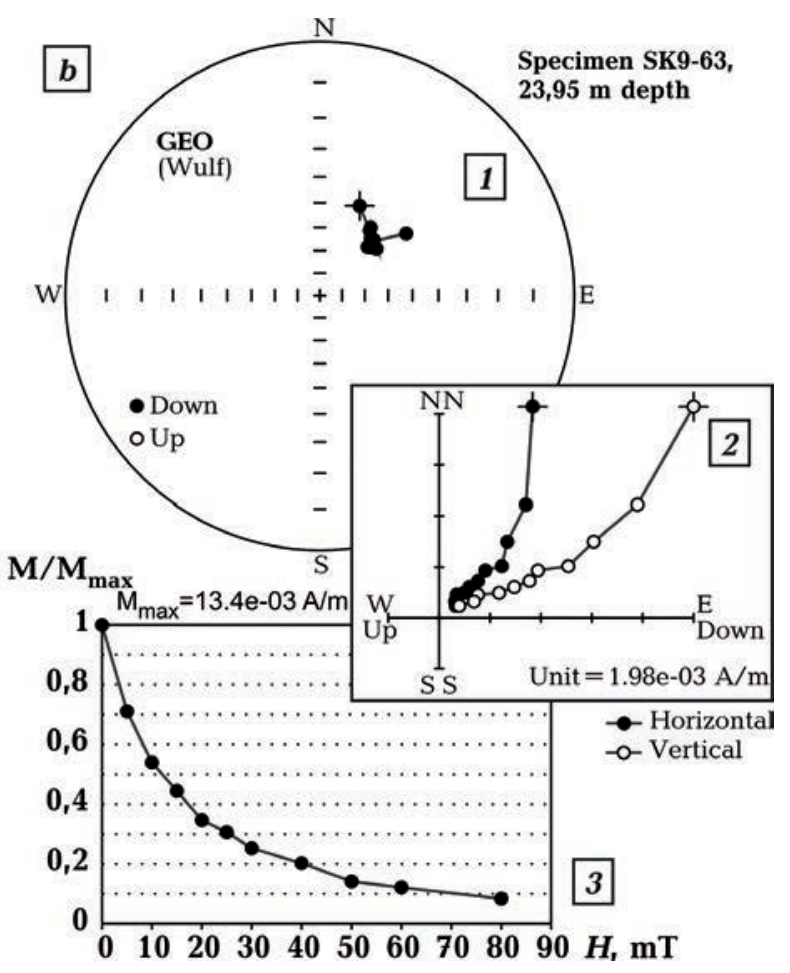

Fig. 5. Examples of stepwise thermal ( $a$ ) and alternating field $(b)$ demagnetization of palaeosol specimens in the Stari Kaydaky section: from the SK-S7S1 $\left(\mathrm{sh}_{3}\right)$ subunit $(a)$; from the SK-S6S1 $\left(\mathrm{mr}_{3}\right)$ subunit $(b)$ : 1 - stereographic projections of demagnetization directions (full and open circles represent projections in the lower and upper hemispheres, respectively); 2 - orthogonal demagnetization paths (Zijderveld diagrams) on horizontal and vertical planes; 3 - NRM intensity decay curves of demagnetization $\left(\mathrm{M} / \mathrm{M}_{\max }\right)$. 
CLP, the S5S1 palaeosol is weakly developed in the western CLP whereas the S4 palaeosol (formed during MIS 11) is the best developed soil in the Quaternary loess-palaeosol sequences [Lu et al., 2018].

Consequently, the SK-S5 pedocomplex at Stari Kaydaky, formed in a more temperate climate, according to the palaeopedological features, might be correlated with MIS 13. In contrast to MIS 11, MIS 13 is regarded as the coolest interglacial of the past $800 \mathrm{ka}$ in different types of long palaeoenvironmental records from all over the world. MIS 13 is characterized by the lower greenhouse gas $\left(\mathrm{CO}_{2}\right.$, $\mathrm{CH}_{4}$ ) concentrations, the cooler Antarctic temperatures and high benthic $\delta^{18} \mathrm{O}$ values [Lisiecki and Raymo, 2005; Lu et al., 2018; Sümegi, 2018 and references therein] which are related to the higher global ice-volume and/or the colder deep ocean temperatures.

These correlations and patterns are in very good correspondence with the palaeoclimate reconstructions obtained from the central Ukrainian loess-palaeosol records in the previous studies. The warmest climate during the Middle Pleistocene (i.e. the Early Middle Pleistocene in the global frameworks) existed during the Early Zavadivka times [Veklich, 1968, 1982; Sirenko, Turlo, 1986; Matviishyna et al., 2010; Gozhik, Gerasimenko, 2011; Sirenko, 2019a], associated with MIS 11 [Gerasimenko, Matvijishyna, 2007], whereas the very cold Tyligul time, reflected in the first glacier appearance in Ukraine, corresponds to MIS 12. According to the above references, the Lower Zavadivka (S4) unit is represented by strongly rubified Luvisol already at the latitude of Stari Kaydaky. The climate of the Lubny warm stage, which is represented by 3-4 soils (Chernozems, Greyzems, Luvisols, and/or Gleysols), is commonly characterized as less warm than that of the Early Zavadivka, and this unit is correlated by the majority of Ukrainian loess researchers with MIS 13-15. Palaeopedological characteristics of SK-S5 at Stari Kaydaky matches well with those of the Lubny pedocomplex elsewhere in the northern and central Ukraine [Sirenko, Turlo, 1986; Gozhik, Gerasimenko, 2011; Sirenko, 2017a,b]. The Tyligul cold stage in- between is correlated with the very extensive glaciation of MIS 12, associated with the advance of large ice sheets in the temperate belt [Lisiecki, Raymo, 2005; Head, Gibbard, 2015].

The next lower soil unit at Vyazivok and Roksolany - Martonosha (S6) — based on the position of the MBB in the underlying Shyrokyne unit, and general assumption about presence of a single MIS 13-15 pedocomplex in Europe, and in Ukraine in particular, has been preliminarily correlated with MIS 17 [Hlavatskyi, Bakhmutov, 2020]. However, MIS 17 was a relatively cold interglacial as it was recorded by global reference curves [Shackleton et al., 1990; Lisiecki, Raymo, 2005; Varga, 2015]. From a pedostratigraphic point of view, the Martonosha soils at Vyazivok, Roksolany, and at Stari Kaydaky as well, are well-developed, rubified forest soils, transitional to subtropical ones, representing a more intense, warmer interglacial period, in contrast to preceding Late Shyrokyne stage and succeeding Lubny stage. Furthermore, the cold event corresponding to MIS 14 is reflected in Lake Baikal, Antarctic, and stacked $\delta^{18} \mathrm{O}$ LR04 palaeoclimatic records. The absolute values of $\delta^{18} \mathrm{O}$ for MIS 14 are commensurate with similar quantities for MIS 8, MIS 34, and MIS 36 treated as glaciations in the LR04-stack [Lisiecki, Raymo, 2005]. Therefore, the correlation of the Martonosha unit with relatively warm MIS 15, and the Upper Shyrokyne unit with colder MIS 17 seems reasonable, but reliable age control is required for more conclusive results.

The position of the MBB in the Ukrainian loess-palaeosol sequences was established, with a high level of confidence, within the Lower Shyrokyne (' $\mathrm{sh}_{1 \mathrm{~b} 1}$ ') subunit, for instance, at Roksolany and Vyazivok [Hlavatskyi, Bakhmutov, 2020]. At Stari Kaydaky, the MBB has not been detected yet as the base of the present profile is located within the upper ' $\mathrm{sh}_{3}$ ' subunit, which has normal polarity elsewhere in the Ukrainian loess sequences [Tretyak, Vigilyanskaya, 1994; Hlavatskyi, 2019; Hlavatskyi et al., 2021b]. In the Brunhes chron, no reversed polarity episodes were identified at Stari Kaydaky as well. 
Conclusions. The palaeoclimatic reconstructions obtained from rock magnetic studies of the three reference sections in the northern, central and southern parts of Ukraine (the Vyazivok, Stari Kaydaky and Roksolany sites) are in a good correspondence regarding the correlation of the units of the Ukrainian stratigraphical framework with the Central European loess-palaeosol nomenclature and with the marine oxygen-isotope stages. Furthermore, the palaeoclimatic signals from the rock magnetic studies of the Vyazivok and Stari Kaydaky sections correspond well to those obtained from the same sites with palaeopedological and palynological methodologies. This leads to high expectation in using multidisciplanary approach (rock magnetism, palaeopedology and palynology), supported by palaeomagnetic studies, for elaboration of reliable reconstructions of the Pleistocene

\section{References}

An, Z. S., Liu, T. S., Zhu, Y. Z., \& Sun, F. (1987). The paleosol complex S5 in the China Loess Plateau - a record of climatic optimum during the last 1.2 Ma. Geojournal, 15, 141-143. https://doi.org/10.1007/BF00157939.

Bakhmutov, V. G., Mokriak, I. N., Skarboviychuk, T. V., \& Yakukhno, V. I. (2005). Results of palaeomagnetic studies of Danube terraces sections and problems of Pleistocene magnetostratigraphy of the west Black Sea region. Geofizicheskiy Zhurnal, 25(6), 980-991 (in Russian).

Bakhmutov, V. G., \& Hlavatskyi, D. V. (2014). New data about Matuyama-Brunhes boundary in Roxolany section. Geological Journal, 347(2), 73-84. http://dx.doi.org/10.30836/igs.10256814.2014.2.139072 (in Russian).

Bakhmutov, V. G., \& Glavatskiy, D. V. (2016). Problems of magnetostratigraphy of Pleistocene loess-soil deposits in the South of Ukraine. Geofizicheskiy Zhurnal, 38(4), 59-75. https://doi. org/10.24028/gzh.0203-3100.v38i4.2016.107801 (in Russian).

Bakhmutov, V. G., Kazanskii, A. Yu., Matasova, G. G., \& Glavatskii, D. V. (2017). Rock magnetism and magnetostratigraphy of the loesssol series of Ukraine (Roksolany, Boyanychi, environmental changes detected from the other loess-palaeosol sequences in Ukraine. The new multidisciplinary studies of the Stari Kaydaky section preliminarily confirm the correlation of the Upper Zavadivka (SKS3) unit with MIS 9, the Lower Zavadivka (SK-S4) unit with MIS 11, the Lubny (SKS5) and Martonosha (SK-S6) units with MIS 13 and MIS 15, respectively, and the Upper Shyrokyne (SK-S7S1) unit with MIS 17. The excavated profile studied at Stari Kaydaky has not reached so far the Lower Shyrokyne unit with the expected Matuyama-Brunhes boundary, found at this stratigraphical level at the two other sections.

Acknowledgments. The research was supported by the National Research Foundation of Ukraine grant 2020.02/0406 «Magnetic proxies of palaeoclimatic changes in the loess-palaeosol sequences of Ukraine».

and Korshev sections). Izvestiya, Physics of the Solid Earth, 53(6), 864-884. https://doi. org/10.1134/S1069351317050020.

Bogucki, A. (1986). Quaternary cover sediments in Volyn-Podillia. In: D. E. Makarenko (Ed.), Quaternary deposits of Ukraine (pp. 121-132). Kiev: Naukova Dumka (in Russian).

Bogucki, A., Gozhik, P., Łanczont, M., Madejska, T., \& Yeovicheva, J. (Eds.). (2013). Proceeding of the XVIII Ukrainain-Polish Workshop 8-13 September 2013. Lublin: KARTPOL s. c. Lublin (in Ukrainian and Polish).

Bogucki, A., Voloshyn, P., \& Tomeniuk, O. (2014). The colapsibility of Pleistocene loess-paleosols and cryogenic levels. Przegląd Geoloczny, 62(2), 553-559 (in Polish).

Boguckyj, A., \& Łanczont, M. (2002). Loess stratigraphy in the Halyc Prydniestrov'ja region. Studia Geologica Polonica, 119, 315-327 (in Polish).

Boguckyj, A. B., Łanczont, M., Łącka, B., Madeyska, T., \& Nawrocki, J. (2009). Quaternary sediment sequence at Skala Podil'ska, Dniester River basin (Ukraine): Preliminary results of multi-proxy analyses. Quaternary International, 198, 173-194. https://doi.org/10.1016/j.quaint. 2008.05.010. 
Bokhorst, M., Beets, C., Marković, S. B., Gerasimenko, N. P., Matviishina, Z. N., \& Frechen, M. (2009). Pedochemical climate proxies in Late Pleistocene loess-soil sequences. Quaternary International, 198(1), 113-123. https://doi. org/10.1016/j.quaint.2008.09.003.

Bolikhovskaya, N. S., \& Molodkov, A. N. (2006). East European loess-palaeosol sequences: Palynology, stratigraphy and correlation. Quaternary International, 149, 24-36. https://doi. org/10.1016/j.quaint.2005.11.015.

Bonchkovskyi, O. S. (2019). Changes in pedogenic processes during Pryluky times (Late Pleistocene) in the central part of the Volyn Upland. Journal of Geology, Geography and Geoecology, 28(2), 230-240. https://doi. org/10.15421/111924.

Bonchkovskyi, O. (2020a). The loess-palaeosol sequence of Novyi Tik: a new Middle and Upper Pleistocene record for Volyn' Upland (northwest Ukraine). Quaternaire, 31(4), 281-308. https://doi.org/10.4000/quaternaire.14308.

Bonchkovskyi, O. S. (2020b). Smykiv - the new key section of the Upper Pleistocene of the Volyn Upland. Visnyk of V. N. Karazin Kharkiv National University. Ser. Geology. Geography. Ecology, 53, 25-44 (in Ukrainian).

Bondar, K., \& Ridush, B. (2015). Rockmagnetic and palaeomagnetic studies of unconsolidated sediments of Bukovynka Cave (Chernivtsi region, Ukraine). Quaternary International, 357, 125-135. https://doi.org/10.1016/j. quaint.2014.04.025.

Bondar, K., Ridush, B., Baryshnikova, M., \& Popiuk, Y. (2019). On palaeomagnetic dating of fluvial deposits in the section of Neporotove gravel quarry on the Middle Dniester. Journal of Geology, Geography and Geoecology, 28(2), 241-249. https://doi.org/10.15421/111925.

Bradák, B., Seto, Y.,\& Nawrocki, J. (2019). Significant pedogenic and palaeoenvironmental changes during the early Middle Pleistocene in Central Europe. Palaeogeography, Palaeoclimatology, Palaeoecology, 534, 109335. https:// doi.org/10.1016/j.palaeo.2019.109335.

Bradák, B., Seto, Y., Stevens, T., Újvári, G., Fehér, K., \& Költringer, C. (2021). Magnetic susceptibility in the European Loess Belt: New and existing models of magnetic enhancement in loess. Palaeogeography, Palaeoclimatology, Palaeoecology, 569, 110329. https://doi.org/10. 1016/j. palaeo.2021.110329.

Buggle, B., Glaser, B., Zöller, L., Hambach, U., Marković, S., Glaser, I., \& Gerasimenko, N. (2008). Geochemical characterization and origin of Southeastern and Eastern European loesses (Serbia, Romania, Ukraine). Quaternary Science Reviews, 27, 1058-1075. https://doi. org/10.1016/j.quascirev.2008.01.018.

Buggle, B., Hambach, B., Glaser, B., Gerasimenko, N., Marković, S., Glaser, I. \& Zöller, L. (2009). Stratigraphy, and spatial and temporal paleoclimatic trends in Southeastern/Eastern European loess - paleosol sequences. Quaternary International, 196, 86-106. https://doi. org/10.1016/j.quaint.2008.07.013.

Buggle, B., Hambach, U., Kehl, M., Marković, S. B., Zoller, L., \& Glaser, B. (2013). The progressive evolution of a continental climate in SE-Central European lowlands during the Middle Pleistocene recorded in loess paleosol sequences. Geology, 41, 771-774. https://doi.org/10.1130/ G34198.1.

Butler, R. F. (1992). Paleomagnetism: magnetic domains to geologic terranes. Boston: Blackwell Scientific Publications, 319 p.

Chadima, M., \& Hrouda, F. (2006). Remasoft 3.0 a user-friendly paleomagnetic data browser and analyzer. Travaux Geophysiques, 27, 20-21.

Chen, J., Yang, T., Matishov, G. G., Velichko, A. A., Zeng, B., He, Y., Shi, P., Fan, Z., Titov, V. V., Borisova, O. K., Timireva, S. N., Konstantinov, E. A., Kononov, Y. M., Kurbanov, R. N., Panin, P. G., \& Chubarov, I. G. (2018). A luminescence dating study of loess deposits from the Beglitsa section in the Sea of Azov, Russia. Quaternary International, 478, 27-37. https:// doi.org/10.1016/j.quaint.2017.11.017.

Chmielowska, D., \& Woronko, B. (2019). A source of loess-like deposits and their attendant palaeoenvironment - Orava Basin, Western Carpathian Mountains, S Poland. Aeolian Research, 38, 60—76. https://doi.org/10.1016/j. aeolia.2019.04.003.

Clemens, S. C., Prell, W. L., Sun, Y., Liu, Z., \& Chen, G. (2008). Southern Hemisphere forcing of Pliocene $\delta^{18} \mathrm{O}$ and the evolution of Indo-Asian monsoons. Palaeoceanography, 23, PA4210. http://dx.doi.org/10.1029/2008PA001638. 
Doroshkevych, S. P. (2018). Pleistocene palaeoenvironment in Middle Pobuzhzhia: according to the study of buried soils. Kyiv: Naukova Dumka, 176 p. (in Ukrainian).

Ehlers, J., Gibbard, P. L., \& Hughes, P. D. (2011). Quaternary Glaciations - Extent and Chronology. Amsterdam: Elsevier, 1126 p.

Evans, M., \& Heller, F. (2001). Magnetism of loess/ palaeosoil sequences: recent development. Earth-Science Reviews, 54, 129-144. http:// dx.doi.org/10.1016/S0012-8252(01)00044-7.

Evans, M. E., \& Heller, F. (2003). Environmental Magnetism. Principles and Applications of Enviromagnetics. Academic Press. 299 p.

Fitzsimmons, K. E., Marković, S. B., \& Hambach, U. (2012). Pleistocene environmental dynamics recorded in the loess of the middle and lower Danube basin. Quaternary Science Reviews, 41, 104-118. https://doi.org/10.1016/j. quascirev.2012.03.002.

Forster, T., \& Heller, F. (1994). Paleomagnetism of loess deposits from the Tajik depression (central Asia). Earth and Planetary Science Letters, 128, 501-512. https://doi.org/10.1016/0012821X(94)90166-X.

Gendler, T. S., Heller, F., Tsatskin, A., Spassov, S., Du Pasquier, J., \& Faustov, S. S. (2006). Roxolany and Novaya Etuliya - key sections in the western Black Sea loess area: Magnetostratigraphy, rock magnetism, and paleopedology. Quaternary International, 152-153, 78-93. https://doi.org/10.1016/j.quaint.2006.01.001.

Gerasimenko, N. (2001). Upper Pleistocene loesspalaeosol and vegetational successions in the Middle Dnieper Area, Ukraine. Studia Quaternaria, 17, 19-28.

Gerasimenko, N. P. (2004). Quaternary Evolution of Zonal Paleoecosystems in Ukraine. Kyiv: Institute of Geography NASU (in Ukrainian).

Gerasimenko, N. (2006). Upper Pleistocene loess-palaeosol and vegetational successions in the Middle Dnieper Area, Ukraine. Quaternary International, 149, 55-66. https://doi. org/10.1016/j.quaint.2005.11.018.

Gerasimenko, N., \& Matvijishyna, Zh. (2007). The problems of Zavadiv "great interglacial». In: A. Bogucki, P. Gozhik, M. Łanczont, L. Lindner, J. Yelovicheva (Eds.), Problems of Middle
Pleistocene interglacial. Proceeding of the XIV Ukrainian-Polish Workshop 12-16 September 2007 (pp. 194-206). Lviv: Vydavnychyi tsentr LNU imeni Ivana Franka (in Ukrainian).

Gerasimenko, N. P. (2020). Quaternary palaeogeography of Ukraine (palaeolandscapes). Kyiv: Print-Service (in Ukrainian).

Gozhik, P., Shelkoplyas, V., \& Khristoforova, T. (1995). Development stages of loessial and glacial formations in Ukraine (Stratigraphy of loesses in Ukraine). Annales UMCS Section B, $50,65-74$.

Gozhik, P. F., Shelkoplyas, V. N., Komar, M. S., Matviishyna, Z. M., \& Perederiy, V. I. (2000). Guide $X$ of the Polish-Ukrainian Seminar "Correlation of loesses and ice deposits». Kyiv: Institute of Geological Sciences of National Academy of Sciences of Ukraine (in Ukrainian).

Gozhik, P., Matviishina, Zh., Shelkoplyas, V., Palienko, V., Rekovets, L., Gerasimenko, N., \& Korniets, N. (2001). The Upper and Middle Pleistocene of Ukraine. In: The Ukraine Quaternary explored: The Middle and Upper Pleistocene of the Middle Dnieper Area and its importance for the East-West correlation (pp. 32-33). Kyiv: IGS NASU.

Gozhik, P., Komar, M., Krokhmal, O., Shovkoplias, V., Khrystoforova, T., Dykan, N., \& Prylypko, S. (2007). The key section of Neopleistocene subaerial deposits near Roxolany village (Odessa region). Institute of Geological Sciences of NAS of Ukraine. In: Problemy serednoplejstocenogo interglacialu (pp. 109-128). Lviv: Vydavnychyi tsentr LNU imeni Ivana Franka (in Ukrainian).

Gozhik, P. F., \& Gerasimenko, N. P. (2011). The lower and middle Pleistocene of Ukraine. In: N. P. Gerasimenko, P. F. Gozhik, N. I. Dykan, Zh. M. Matviishyna, V. M. Shelkoplyas, B. D. Vozgrin (Eds.), Quaternary studies in Ukraine (pp. 9-26). Kyiv: Institute of Geological Sciences NASU.

Gozhik, P. F. (Ed.). (2012). Stratigraphic code of Ukraine. Kyiv: National Stratigraphic Committee of Ukraine (in Ukrainian).

Guo, Z., Berger, A., Yin, Q. Z., \& Quin, L. (2009). Strong asymmetry of hemispheric climates during MIS-13 inferred from correlating China loess and Antarctica ice records. Climate 
of the Past, 5, 21-31. https://doi.org/10.5194/ ср-5-21-2009.

Haase, D., Fink, J., Haase, G., Ruske, R., Pesci, M., Richter, H., Altermann, M., \& Jager, K.-D. (2007). Loess in Europe - Its spatial distribution based on a European Loess Map, scale 1:2,500,000. Quaternary Science Reviews, 26, 1301-1312. https://doi.org/10.1016/j.quascirev.2007.02.003.

Haesaerts, P., Borziak, Il., Chirica, V., Damblon, F., Koulakovska, L., \& Van Der Plicht, J. (2003). The East-Carpathian loess record: a reference for the Middle and Late Pleniglacial stratigraphy in Central Europe. Quaternaire, 14(3), $163-188$.

Haesaerts, P., Gerasimenko, N., Damblon, F., Spagna, P., \& Pirson, S. (2016). The Late Pleistocene loess-palaeosol sequence of Middle Belgium. Quaternary International, 411, 1-19. https:// doi.org/10.1016/j.quaint.2016.02.012.

Haesaerts, P., Gerasimenko, N., Damblon, F., Yurchenko, T., Kulakovska, L., Usik, V., \& Ridush, B. (2019). The Upper Paleolithic site Doroshivtsi III: a new chronostratigraphic and environmental record of the Late Pleniglacial in the regional context of the Middle DniesterPrut loess domain (Western Ukraine). Quaternary International, 546, 196-215. https://doi. org/10.1016/j.quaint.2019.12.018.

Head, M. J., \& Gibbard, P. L. (2015). Early-Middle Pleistocene transitions: linking terrestrial and marine realms. Quaternary International, 389, 7-46. https://doi.org/10.1016/j.quaint.2015. 09.042 .

Heller, F., \& Liu, T. (1984). Magnetism of Chinese loess deposites. Geophysical Journal International, 77, 125-141. https://doi.org/10.1111/ j.1365-246X.1984.tb01928.X.

Hlavatskyi, D., Bakhmutov, V., Bogucki, A., \& Voloshyn, P. (2016a). Petromagnetism and paleomagnetism of subaerial deposits of Boyanychi and Korshiv sections (Volhynian Upland). Visnyk of Taras Shevchenko National University of Kyiv: Geology, 72(1), 43-51. https://doi. org/10.17721/1728-2713.72.06 (in Ukrainian).

Hlavatskyi, D. V., Kuzina, D. M., Gerasimenko, N. P., \& Bakhmutov, V. G. (2016b). Petromagnetism and paleomagnetism of Quaternary loess-soil sediments of Vyazivok section (Dnieper Lowland). Geofizicheskiy Zhurnal, 38(6), 186-
193. https://doi.org/10.24028/gzh. 0203-3100. v38i6.2016.91903 (in Russian).

Hlavatskyi, D. V. (2019). Refined magnetostratigraphic position of the Shyrokyne unit in loess sequences from Central Ukraine. Journal of Geology, Geography and Geoecology, 28(2), 301-312. https://doi.org/10.15421/111930.

Hlavatskyi, D. V., \& Bakhmutov, V. G. (2019). Magnetostratigraphy of the key loess-palaesol sequence at Roxolany (Western Black Sea region). In: D. Nurgaliev, V. Shcherbakov, A. Kosterov, S. Spassov (Eds.), Recent Advances in Rock Magnetism, Environmental Magnetism and Paleomagnetism (pp. 371-382). Springer Geophysics. Springer, Cham. https://doi. org/10.1007/978-3-319-90437-5_26.

Hlavatskyi, D. V., \& Bakhmutov, V. G. (2020). Magnetostratigraphy and magnetic susceptibility of the best developed Pleistocene loess-palaeosol sequences of Ukraine: implications for correlation and proposed chronostratigraphic models. Geological Quarterly, 64(3), 723-753. https://doi.org/10.7306/gq.1544.

Hlavatskyi, D., Gerasimenko, N., Bakhmutov, V., Bonchkovskyi, O., Poliachenko, I., Shpyra, V., Kravchuk, I., \& Cherkes, S. (2021a). Reconstruction of the Pleistocene climate change in the Middle Dnieper area on the basis of rock magnetic, palaeopedological and pollen studies of two reference loess-palaeosol sequences. EGU General Assembly 2021, online, 19-30 April 2021, EGU21-1758. https://doi.org/10.5194/ egusphere-egu21-1758.

Hlavatskyi, D. V., Stepanchuk, V. N., Kuzina, D. M., Poliachenko, I. B., Shpyra, V. V., Skarboviychuk, T. V., Yakukhno, V. I., \& Bakhmutov, V. G. (2021b). Rock magnetic and palaeomagnetic studies of loess-palaesol sections - Lower Palaeolithic sites within the Southern Bug Valley (Medzhybizh, Holovchyntsi). Geofizicheskiy Zhurnal, 43(1), 3-37. https://doi.org/10.24028/ gzh.0203-3100.v43i1.2021.225539 (in Russian).

Jordanova, D., \& Petersen, N. (1999). Paleoclimatic record from a loess - soil profile in northeastern Bulgaria II. Correlation with global climatic events during the Pleistocene. Geophysical Journal International, 138, 533-540. https:// doi.org/10.1046/j.1365-246X.1999.00873.x.

Jordanova, D., \& Jordanova, N. (2021). Updating the significance and paleoclimate implica- 
tions of magnetic susceptibility of Holocene loessic soils. Geoderma, 391, 114982. https:// doi.org/10.1016/j.geoderma.2021.114982.

Karmazinenko, S. (2019). Pleistocene soils of the Azov Lowland, Ukraine. Journal of Geology, Geography and Geoecology, 28(2), 313-326. https: //doi.org/https://doi.org/10.15421/ 111931 .

Költringer, C., Stevens, T., Bradák, B., Almqvist, B., Kurbanov, R., Snowball, I., \& Yarovaya, S. (2020). Enviromagnetic study of Late Quaternary environmental evolution in Lower Volga loess sequences, Russia. Quaternary Research, 1-25. http://dx.doi.org/10.1017/qua.2020.73.

Krokos, V. I. (1926). Short description of the Quaternary deposits of Ukraine. Bulletin of MOIP, sect. Geologia, 4, 214-264 (in Russian).

Kukla, G., Heller, F., Liu, X. M., Xu, T. C., Liu, T. S., \& An, Z. S. (1988). Pleistocene climates in China dated by magnetic susceptibility. Geology, 16, 811-814. https://doi.org/10.1130/00917613(1988)016\%3C0811:PCICDB\%3E2.3.CO;2.

Laag, C., Jordanova, D., Lagroix, F., Jordanova, N., \& Guyodo, Y. (2021). A new reference loesspaleosol archive spanning the last 850 kyrs near Pleven (Bulgaria) - first results. EGU General Assembly 2021, online, 19-30 Apr 2021, EGU21-6381. https://doi.org/10.5194/ egusphere-egu21-6381.

Łanczont, M., \& Boguckyj, A. (2007). High-resolution terrestrial archive of climatic oscillations during Oxygen Isotope Stages 5-2 in the loess-palaeosol sequence at Kolodiiv (East Carpathian Fore land, Ukraine). Geological Quarterly, 51(2), 105-126.

Łanczont, M., Madeyska, T. (Eds.). (2015). Palaeolithic oecumene in the peri-and meta-Carpathian zone. Lublin: Wydawnictwo UMCS, 972 p. (in Polish).

Łanczont, M., Bogucki, A., Yatsyshyn, A., Terpiłowski, S., Mroczek, P., Orłowska, A., Hołub, B., Zieliński, P., Komar, M., Woronko, B., Kulesza, P., Dmytruk, R., \& Tomeniuk, O. (2019). Stratigraphy and chronology of the periphery of the Scandinavian ice sheet at the foot of the Ukrainian Carpathians. Palaeogeography, $\mathrm{Pa}$ laeoclimatology, Palaeoecology, 530, 59-77. https://doi.org/10.1016/j.palaeo.2019.05.024.

Lindner, L., Bogutsky, A., Gozhik, P., Marks, L., Łanczont, M., \& Wojtanowicz, J. (2006). Cor- relation of Pleistocene deposits in the area between the Baltic and Black Sea, Central Europe. Geological Quarterly, 50(1), 195-210.

Lisiecki, L. E., \& Raymo, M. E. (2005). A PliocenePleistocene stack of 57 globally distributed benthic $\delta 18 \mathrm{O}$ records. Paleoceanography, 20, PA1003. https://doi.org/10.1029/2004PA001071.

Lu, H., Jia, J., Wang, Y., Yin, Q., \& Xia, D. (2018). The cause of extremely high magnetic susceptibility of the S5S1 paleosol in the central Chinese Loess Plateau. Quaternary International, 493, 252-257. https://doi.org/10.1016/j. quaint.2018.05.046.

Maher, B. A. (2011). The magnetic properties of Quaternary aeolian dusts and sediments, and their palaeoclimatic significance. Aeolian Research, 3(2), 87-144. https://doi.org/10.1016/j. aeolia.2011.01.005.

Malyasova, T. I., \& Spiridonova, E. S. (1989). Methodology for preparing samples of the loess-soil succession for spore-pollen analysis. Vestnik Leningradskogo universiteta. Ser. Geografia, 2 , 5-12 (in Russian).

Marković, S. B., Stevens, T., Kukla, G. J., Hambach, U., Fitzsimmons, K. E., Gibbard, P., Buggle, B., Zech, M., Guo, Z., Hao, Q., Wu, H., O'Hara Dhand, K., Smalley, I. J., Újvári, G., Sümegi, P., Timar-Gabor, A., Veres, D., Sirocko, F., Vasiljević, D. A., Jary, Z., Svensson, A., Jović, V., Lehmkuhl, F., Kovács, J., \& Svirčev, Z. (2015). Danube loess stratigraphy - Towards a panEuropean loess stratigraphic model. Earth Science Reviews, 148, 228-258. https://doi. org/10.1016/j.earscirev.2015.06.005.

Marković, S. B., Stevens, T., Mason, J., Vandenberghe, J., Yang, S., Veres, D., Újvári, G., TimarGabor, A., Zeeden, C., Guo, Z., Hao, Q., Obreht, I., Hambach, U., Wu, H., Gavrilov, M. B., Rolf, C., Tomid, N., \& Lehmkuhl, F. (2018). Loess correlations - Between myth and reality. Palaeogeography, Palaeoclimatology, Palaeoecology, 509, 4-23. https://doi.org/10.1016/j. palaeo.2018.04.018.

Matasova, G. G., \& Kazansky, A. Yu. (2004). Magnetic properties and magnetic fabrics of Pleistocene loess/palaeosol deposits along westcentral Siberian transect and their palaeoclimatic implications. Geological Society, London, Special Publications, 238(1), 145. http://dx.doi. org/10.1144/GSL.SP.2004.238.01.11. 
Matviishina, Zh., Mel'nichuk, I., Perederyi, V., \& Gerasimenko, N. (2001). Vyazivok section. In: The Ukraine Quaternary explored: the Middle and Upper Pleistocene of the Middle Dnieper are and its importance for the East-West European correlation. Excursion guide of the SEQS 2001 conference, Ukraine (pp. 23-36). Kyiv: Institute of Geological Sciences NASU.

Matviishyna, Zh. M., Gerasimenko, N. P., Perederyi, V. I., Bragin, A. M., Ivchenko, A. S., Karmazinenko, S. P., Nagirnyi, V. M., \& Parkhomenko, O. G. (2010). Spatio-temporal correlation of Quaternary palaeogeographic conditions on the territory of Ukraine. Kyiv: Naukova Dumka, 191 p. (in Ukrainian).

Matviishyna, Zh. M., \& Doroshkevych, S. P. (2019). Micromorphological peculiarities of the Pleistocene soils in the Middle Pobuzhzhya (Ukraine) and their significance for palaeogeographic reconstructions. Journal of Geology, Geography and Geoecology, 28(2), 327-347.

Menshov, O. (2015). Magnetic susceptibility of the southern chernozems of Ukraine, case study from Odessa region. Visnyk of Taras Shevchenko National University of Kyiv: Geology, 69(2), 70-74. https://doi.org/10.17721/1728-2713.69. 11.70-74 (in Ukrainian).

Menshov, O. (2019). Application of magnetic methods for the monitoring of the natural and manmade processes associated with critical infrastructure objects. Visnyk of Taras Shevchenko National University of Kyiv: Geology, 84(1), 27-33. https://doi.org/10.17721/1728-2713.84. 04 (in Ukrainian).

Molnár, D, Makó, L., Cseh, P., Sümegi, P., Fekete, I., \& Galović, L. (2021). Middle and Late Pleistocene loess-palaeosol archives in East Croatia: multi-proxy palaeoecological studies on Zmajevac and Šarengrad II sequences. Studia Quaternaria, 38(1), 3-17. https://doi.org/10.24425/ sq.2020.133758.

Nawrocki, J., Bakhmutov, V., Bogucki, A., \& Dolecki, L. (1999). The Paleo- and Petromagnetic record in the Polish and Ukrainian Loess-Paleosol Sequences. Physics and Chemistry of the Earth (A), 24, 773-777. https://doi.org/10.1016/ S1464-1895(99)00113-1.

Nawrocki, J., Bogucki, A., Łanczont, M., \& Nowaczyk, N. (2002). The Matuyama-Brunhes boundary and the nature of magnetic remanence aquisition in the loess-paleosol sequences from the western part of the East European Loess province. Palaeogeography, Palaeoclimatology, Palaeoecology, 188, 39-50. http://dx.doi. org/10.1016/S0031-0182(02)00528-X.

Nawrocki, J., Łanczont, M., Rosowiecka, O., \& Bogucki, A. B. (2016). Magnetostratigraphy of the loess-palaeosol key Palaeolithic section at Korolevo (Transcarpathia, W Ukraine). Quaternary International, 399, 72-85. https://doi. org/10.1016/j.quaint.2014.12.063.

Nawrocki, J., Gozhik, P., Łanczont, M., Pańczyk, M., Komar, M., Bogucki, A., Williams, J. S., \& Czupy, Z. (2018). Palaeowind directions and sources of detrital material archived in the Roxolany loess section (southern Ukraine). Palaeogeography, Palaeoclimatology, Palaeoecology, 496, 121-135. https://doi.org/ 10.1016/j.palaeo.2018.01.028.

Necula, C., Dimofte, D., \& Panaiotu, C. (2015). Rock magnetism of a loess-palaeosol sequence from the western Black Sea shore (Romania). Geophysical Journal International, 202, 17331748. https://doi.org/10.1093/gji/ggv250.

Railsback, B. L., Gibbard, P. L., Head, M. J., Voarintsoa, Ny, R. G., \& Toucanne, S. (2015). An optimized scheme of lettered marine isotope substages for the last 1.0 million years, and the climatostratigraphic nature of isotope stages and substages. Quaternary Science Reviews, 111, 94-106. https://doi.org/10.1016/j.quascirev.2015.01.012.

Rousseau, D.-D., Gerasimenko, N., Matviischina, Zh., \& Kukla, G. (2001). Late Pleistocene Environments of the Central Ukraine. Quaternary Research, 56, 349-356. https://doi. org/10.1006/qres.2001.2270.

Rousseau, D.-D., Antoine, P., Gerasimenko, N., Sima, A., Fuchs, M., Hatté, C., Moine, O., \& Zoeller, L. (2011). North Atlantic abrupt climatic events of the last glacial period recorded in Ukrainian loess deposits. Climate of the Past, 7, 221-234. https://doi.org/10.5194/cp-7-2212011.

Scheidt, S., Berg, S., Hambach, U., Klasen, N., Pötter, S., Stolz, A., Veres, D., Zeeden, C., Brill, D., Brückner, H., Kusch, S., Laag, C., Lehmkuhl, F., Melles, M., Monnens, F., Oppermann, L., Rethemeyer, J., \& Nett, J. J. (2021). Chronological Assessment of the Balta Alba Kurgan Loess- 
Paleosol Section (Romania) — A Comparative Study on Different Dating Methods for a Robust and Precise Age Model. Frontiers in Earth Science, 8, 586. https://doi.org/10.3389/ feart.2020.598448.

Shackleton, N. J., Berger, A., \& Peltier, W. R. (1990). An alternative astronomical calibration of the lower Pleistocene timescale based on ODP Site 677. Transactions of the Royal Society of Edinburgh Earth Sciences, 81, 251-261. https://doi.org/10.1017/S0263593300020782.

Sirenko, N. A., \& Turlo, S. I. (1986). Successions of soils and vegetation of Ukraine during the Pliocene and Pleistocene. Kyiv: Naukova Dumka, 488 p. (in Russian).

Sirenko, O. (2017a). Palynostratigraphy of Continental Upper Pliocene-Lower Neopleistocene Deposits of Southern Part of the East European Platform. Kyiv: Naukova Dumka, 165 p. (in Russian).

Sirenko, O. (2017b). Subaeral EopleistoceneLower Neopleistocene deposits of the plain part of Ukraine and their palynological characteristic. Dnipropetrovsk University Bulletin. Ser. Geology, Geography, 25(1), 101-118 (in Ukrainian). https://doi.org/10.15421/111712.

Sirenko, O. (2019a). Changes in Pleistocene vegetation and climate of Ukraine in the range of 1.8-0.4 million years. Journal of Geology, Geography and Geoecology, 28, 355-366. https:// doi.org/10.15421/111934.

Sirenko, O. (2019b). Palynological data on the description of the Gelasian and Calabriane analogues in the stratotype section of the Kuyalnik deposits near Kryzhanivka village (Odessa region). Journal of Geology, Geography and Geoecology, 28(4), 727-737. https://doi.org/ https://doi.org/10.15421/111968.

Song, Y., Guo, Z., Marković, S., Hambach, U., Deng, C., Chang, L., Wu, J., \& Hao, Q. (2018). Magnetic stratigraphy of the Danube loess: a composite Titel-Stari Slankamen loess section over the last one million years in Vojvodina, Serbia. Journal of Asian Earth Sciences, 155, 68-80. https://doi.org/10.1016/j. jseaes.2017.11.012.

Sümegi, P., Náfrádi, K., Molnár, D., \& Sávai, Sz. (2015). Results of palaeoecological studies in the loess region of Szeged-Öthalom (SE Hun- gary). Quaternary International, 357, 1-13. https://doi.org/10.1016/j.quaint.2014.09.003.

Sümegi, P., Gulyás, S., Molnár, D., Sümegi, B. P., Almond, P. C., Vandenberghe, J., Zhou, L., PálMolnár, E., Törőcsik, T., Hao, Q., Smalley, I., Molnár, M., \& Marsi, I. (2018). New chronology of the best developed loess/paleosol sequence of Hungary capturing the past 1.1 ma: Implications for correlation and proposed pan-Eurasian stratigraphic schemes. Quaternary Science Reviews, 191, 144-166. https://doi.org/ 10.1016/j.quascirev.2018.04.012.

Sümegi, P., Gulyás, S., Molnár, D., Sümegi, B. P., Törőcsik, T., Almond, P. C., \& Koloszár, L. (2019). Periodicities of paleoclimate variations in the first high-resolution non-orbitally tuned grain size record of the past $1 \mathrm{Ma}$ from SW Hungary and regional, global correlations. Aeolian Research, 40, 74-90. https://doi. org/10.1016/j.aeolia.2019.07.002.

Tecsa, V., Gerasimenko, N., Veres, D., Hambach, U., Lehmkuhl, F., Schulte, P., \& TimarGabor, A. (2020). Revisiting the chronostratigraphy of Late Pleistocene loess-paleosol sequences in southwestern Ukraine: OSL dating of Kurortne section. Quaternary International, 542, 65-79. https://doi.org/10.1016/j.quaint. 2020.03.001.

Tretyak, A. N., \& Volok, Z. E. (1976). Paleomagnetic stratigraphy of Pliocene and Quaternary sediments in Ukraine. Kiev: Naukova Dumka, 88 p. (in Russian).

Tretyak, A. N. (1980). Regim of the Pleistocene geomagnetic field and structure of the Brunhes geomagnetic epoch. Geofizicheskiy Zhurnal, 5(2), 75-87 (in Russian).

Tretyak, A. N. (1983). Natural remnant magnetization and problem of sediments paleomagnetic stratification. Kiev: Naukova Dumka, 256 p. (in Russian).

Tretyak, A. N., Shevchenko, A. I., Dudkin, V. P., \& Vigilyanskaya, L. I. (1987). Paleomagnetic stratigraphy of key Late Cenozoic sections of the south of Ukraine. Kiev: Institute of Geological Sciences AS USSR, 50 p. (in Russian).

Tretyak, A. N., Vigilyanskaya, L. I., Makarenko, V. N., \& Dudkin, V. P. (1989). Thin structure of geomagnetic field in Late Cenozoic. Kiev: Naukova Dumka, 156 p. (in Russian). 
Tretyak, A. N., \& Vigilyanskaya, L. I. (1994). Magnetostratigraphic scale of Pleistocene of Ukraine. Geofizicheskiy Zhurnal, 16(2), 3-14 (in Russian).

Vandenberghe, J., \& Nugteren, G. (2001). Rapid climatic changes recorded in loess successions. Global and Planetary Change, $28,1-9$. https:// doi.org/10.1016/S0921-8181(00)00060-6.

Varga, G. (2015). Changing nature of Pleistocene interglacials - is it recorded by paleosoils in Hungary (Central Europe). Hungarian Geographical Bulletin, 64(4), 317-326. https://doi.org/ 10.15201/hungeobull.64.4.6.

Veklitch, M. F., Artyushenko, A. T., Sirenko, N. A., Dubnyak, V. A., Mel'nichuk, I. V., \& Parishkura, S. I. (1967). Key Sections of the Anthropogene of Ukraine (pp. 13-50). Kiev: Naukova Dumka (in Russian).

Veklitch, M. F. (1968). Stratygraphy of the loess formation of Ukraine and adjacent countries. Kiev: Naukova Dumka, 201 p. (in Russian).

Veklitch, M. F., \& Sirenko, N. A. (1972). Key Sections of the Anthropogene of Ukraine. Part III. Kiev: Naukova Dumka, 225 p. (in Russian).

Veklitch, M. F, Matviishyna, Zh. N., Medvedev, V. V., Sirenko, N. A., \& Federov, K. N. (1979). Palaeosol research methodology. Kiev: Naukova Dumka, 272 p. (in Russian).

Veklitch, M. F. (1982). Stages and stratotypes of the soil formations of Ukraine in the Upper Cenozoic. Kiev: Naukova Dumka (in Russian).

Veklitch, M. F., Sirenko, N. A., Matviishyna, Zh. N., Melnychuk, I. V., Perederyi, V. I., Turlo, S. I., \& Vozgrin, B. D. (1984). Palaeogeographical succession and detailed stratigraphic division of the Pleistocene of Ukraine (methodological developments). Kiev: Naukova Dumka, 32 p. (in Russian).

Veklitch, M. F, Sirenko, N. A, Matviishyna, Zh. N., Gerasimenko, N. P., Perederiy, V. I., \& Turlo, S. I. (1993). The Pleistocene stratigraphical framework of the Ukraine. Stratigraficheskiye skhemy fanerozoya i dokembriya Ukrainy. Kiev: State Committee of Geology of Ukraine (in Russian).
Veklych, Y. (2019). Map of Quaternary formations of Ukraine in scale 1:2,500,000. Journal of Geology, Geography and Geoecology, 28(2), 367-376. https://doi.org/https://doi.org/10. $15421 / 111935$.

Velichko, A. A. (Ed.) (1997). Loess-palaeosol formation of the East-European Plain. Moscow, 140 p. (in Russian).

Veres, D., Tecsa, V., Gerasimenko, N., Zeeden, C., Hambach, U., \& Timar Gabor, A. (2018). Shortterm soil formation events in the last glacial east European loess, evidence from multi-method luminescence dating. Quaternary Science Reviews, 200, 34-51. https://doi.org/10.1016/j. quascirev.2018.09.037.

Vigilyanskaya, L. I., \& Tretyak, A. N. (2001). Palaeomagnetism of Reference Sections in Pliocene-Pleistocene Deposits of the NW Donbas. Geophysical Journal, 22, 523-535.

Vigilyanskaya, L. I., \& Tretyak, A. N. (2002). Palaeomagnetic studies of Pliocene-Pleistocene deposits of loess-palaeosol stratum in Middle Dnieper region. Geofizicheskiy Zhurnal, 24(5), 36-42 (in Russian).

Wacha, L., Laag, C., Grizelj, A., Tsukamoto, S., Zeeden, C., Ivanišević, D., Rolf, C., Banak, A., \& Frechen, M. (2021). High-resolution palaeoenvironmental reconstruction at Zmajevac (Croatia) over the last three glacial/interglacial cycles. Palaeogeography, Palaeoclimatology, Palaeoecology, 576, 110504. https://doi. org/10.1016/j.palaeo.2021.110504.

Zeeden, C., Hambach, U., Obreht, I., Hao, Q., Abels, H. A., Lehmkuhl, F., Gavrilov, M. B., \& Marković, S. B. (2018). Patterns and timing of loess-paleosol transitions in Eurasia: Constraints for paleoclimate studies. Global and Planetary Change, 162, 1-7. https://doi. org/10.1016/j.gloplacha.2017.12.021.

Zeeden, C., \& Hambach, U. (2021). Magnetic Susceptibility Properties of Loess From the Willendorf Archaeological Site: Implications for the Syn/Post-Depositional Interpretation of Magnetic Fabric. Frontiers in Earth Science, 8, 709. https://doi.org/10.3389/feart.2020.599491. 


\title{
Значимость лессово-почвенной формации Украины Аля реконструкций изменений климата в плейстоцене: петромагнитные, палеопедологические и палинологические индикаторы
}

\author{
А. В. ГАавацкий, Н. П. Герасименко ${ }^{2}$, В. Г. Бахмутов ${ }^{1}$, О. С. Бончковский ${ }^{2}$, \\ Е. Б. Поляченко ${ }^{1}$, В. В. Шпыра ${ }^{1}$, С. В. Мычак ${ }^{1}$, И. В. Кравчук ${ }^{2}$, \\ С. И. Черкес ${ }^{1}, 2021$ \\ ${ }^{1}$ Институт геофизики им. С. И. Субботина НАН Украины, Киев, Украина
${ }^{2}$ Киевский национальный университет имени Тараса Шевченко, Киев, Украина
}

Вариации петромагнитных характеристик в лессово-почвенных породах, обусловленные изменением климатических и ландшафртных условий их формирования, являются мощным инструментом применения этих параметров как индикаторов при палеоклиматических реконструкциях. Определение закономерностей изменения магнитных параметров, установленных в лессово-почвенных отложениях Украины, в зависимости от динамики палеоклиматов и древней природной среды, и, как следующий шаг, оценка их информативности и значимости для палеореконструкций выполняются в рамках проекта Национального фонда исследований Украины 2020.02/0406 «Магнитные индикаторы палеоклиматических изменений в отложениях лессово-почвенной формации Украины». Палеоэкологические реконструкции выполняются с использованием значительного количества палеоиндикаторов: педостратиграфии, литологии, морфологии ископаемых почв, палинологии и широкого спектра петромагнитных характеристик. В этой статье представлен мультидисциплинарный подход к реконструкциям древней природной среды, осуществляемый в проекте, а также предварительные результаты корреляции педостратиграфических (частично палинологических) данных с показателями магнитной восприимчивости лессово-почвенных пород в северной, центральной и южной частях Украинской лессовой провинции. Выполнено сравнение петромагнитных параметров трех наиболее полных лессово-почвенных разрезов в бассейне Анепра и на Причерноморской низменности (Старые Кайдаки, Вязовок и Роксоланы). Амплитуды палеоклиматических изменений, установленные по магнитным индикаторам, хорошо сопоставляются с результатами литолого-палеопедологических и палинологических исследований этих разрезов, и с глобальной морской кислородно-изотопной шкалой (MIS). Петромагнитные, педостратиграфические и палинологические исследования разреза Старые Кайдаки позволяют предварительно предположить корреляцию верхнезавадовского $\left(\mathrm{zv}_{3}\right)$ и нижнезавадовского $\left(\mathrm{zv}_{1}\right)$ климатолитов с MIS 9 и MIS 11, соответственно, как это было ранее показано для разрезов Вязовок и Роксоланы. Нижезалегающий лубенский педокомплекс (lb), вероятно, может соответствовать MIS 13, а мартоношский педокомплекс (mr) - MIS 15. В ходе палеомагнитных исследований разреза Старые Кайдаки еще не была опробована нижняя часть разреза, в частности, нижнеширокинский субклиматолит $\left(\mathrm{sh}_{1}\right)$, в котором в Роксоланах и Вязовке была определена граница Матуяма-Брюнес. Верхнеширокинский почвенный горизонт $\left(\mathrm{sh}_{3}\right)$ характеризуется прямой полярностью и предварительно сопоставляется с MIS 17. В рамках проекта будут проводиться дальнейшие исследования разреза Старые Кайдаки и других лессово-почвенных профилей.

Ключевые слова: лессово-почвенная формация, петромагнетизм, магнитная восприимчивость, палеопедология, палинология, палеоклимат, стратиграфическая корреляция. 


\title{
Важливість лесово-грунтової формації України Аля реконструкцій змін клімату в плейстоцені: петромагнітні, палеопедологічні і палінологічні індикатори
}

\author{
А. В. ГАавацький ${ }^{1}$ Н. П. Герасименко ${ }^{2}$, В. Г. Бахмутов ${ }^{1}$, \\ О. С. Бончковський ${ }^{2}$, С. Б. Поляченко ${ }^{1}$, В. В. Шпира ${ }^{1}$, С. В. Мичак', \\ I. В. Кравчук ${ }^{2}$, С. I. Черкес ${ }^{1}, 2021$ \\ ${ }^{1}$ Інститут геофізики ім. С. І. Субботіна НАН України, Київ, Україна \\ ${ }^{2}$ Київський національний університет імені Тараса Шевченка, Київ, Україна
}

Варіації петромагнітних параметрів у лесово-грунтовій формації, зумовлені кліматичними й ландшафтними умовами фрормування порід, є потужним інструментом застосування їх як індикаторів при палеокліматичних реконструкціях. Визначення закономірностей змін магнітних параметрів у лесово-грунтових відкладах України залежно від динаміки палеокліматів і давнього природного середовища i, таким чином, оцінювання їхньої інформативності для палеореконструкцій виконується у рамках проєкту Національного фонду досліджень України 2020.02/0406 «Магнітні індикатори палеокліматичних змін у відкладах лесово-грунтової формації України». У проєкті палеоекологічні реконструкції здійснюють із використанням значної кількості палеоіндикаторів: морфологічних та літологічних властивостей викопних грунтів і лесів, їхніх паліноспектрів і широкого набору магнітних параметрів. У цій статті представлено мультидисциплінарний підхід до реконструкції давньої природи, пропонований проєктом, і наведено попередні результати зіставлення педостратиграфічних, частково палінологічних, даних із показниками магнітної сприйнятливості відкладів у розрізах лесово-грунтової формації у північних, центральних і південних районах України. Виконано порівняння за петромагнітними параметрами трьох найбільш повних лесово-грунтових розрізів у басейні Аніпра та на Причорноморській низовині (Старі Кайдаки, В'язівок і Роксолани). Амплітуди палеокліматичних змін, встановлені за магнітними індикаторами, добре зіставляються із результатами літологопалеопедологічних і палінологічних досліджень цих же розрізів та із глобальною морською киснево-ізотопною шкалою (MIS). Петромагнітні, педостратиграфічні й палінологічні дослідження розрізу Старі Кайдаки дають змогу попередньо корелювати верхньозавадівський $\left(\mathrm{zv}_{3}\right)$ і нижньозавадівський $\left(\mathrm{zv}_{1}\right)$ кліматоліти із MIS 9 та MIS 11 відповідно, як було раніше запропоновано для розрізів В'язівок і Роксолани. Припускається, що сформований до завадівського лубенський педокомплекс (lb) може відповідати MIS 13, а мартоноський педокомплекс (mr) - MIS 15. Опробування на палеомагнітні дослідження ще не досягло найнижчої частини розрізу Старі Кайдаки, зокрема, нижньоширокинського субкліматоліту $\left(\mathrm{sh}_{1}\right)$, у якому було встановлено межу Матуяма-Брюнес у Роксоланах і В'язівку. Верхньоширокинський грунтовий горизонт $\left(\mathrm{sh}_{3}\right)$ характеризується прямою полярністю і попередньо зіставляється із MIS 17. У рамках проєкту проводитимуться подальші дослідження розрізу Старі Кайдаки та інших лесово-грунтових відслонень.

Ключові слова: лесово-грунтова формація, петромагнетизм, магнітна сприйнятливість, палеопедологія, палінологія, палеоклімат, стратиграфічна кореляція. 